Portland State University

PDXScholar

$5-24-2018$

\title{
“Living Day by Day" Refugees of Color Navigate Gentrification and Racism in Portland, Oregon: a Sense of Place
}

Serena Dressel

Portland State University

Follow this and additional works at: https://pdxscholar.library.pdx.edu/honorstheses

Let us know how access to this document benefits you.

\section{Recommended Citation}

Dressel, Serena, "'Living Day by Day" Refugees of Color Navigate Gentrification and Racism in Portland, Oregon: a Sense of Place" (2018). University Honors Theses. Paper 541.

https://doi.org/10.15760/honors.547

This Thesis is brought to you for free and open access. It has been accepted for inclusion in University Honors Theses by an authorized administrator of PDXScholar. Please contact us if we can make this document more accessible: pdxscholar@pdx.edu. 
"Living Day by Day" Refugees of Color Navigate Gentrification and Racism in Portland, Oregon: A Sense of Place

\section{Serena Dressel}

An undergraduate honors thesis submitted in partial fulfillment of the requirements for the degree of

Bachelor of Science

in

University Honors

and

Environmental Studies

Thesis Adviser

Hunter Shobe, $\mathrm{PhD}$ 


\section{ABSTRACT}

This research highlights the impact that rising rent prices have on refugees' sense of place in Portland. The majority of Oregon's refugee population arrive in Portland, the fourth fastest gentrifying city in the United States. Refugees receive eight months of financial assistance upon arrival, an average of $\$ 339$ per month. Employees from the Immigrant Refugee Community Organization were interviewed including refugees, an asylee, and immigrants from Bhutan, Myanmar/Burma, Chad, Iraq, and Somalia. One employee from Catholic Charities was interviewed. Positive perceptions include natural amenities, that it is considered safe and small, the progressive political climate, and community presence $\&$ support. They all said they would stay as long as they could afford to, indicating they had developed an attachment to place. Negative themes found include gentrification, racism, and displacement. Many of the refugees moved to rural areas that are conservative, leaving them isolated from their communities, distanced from resources and potentially more likely to experience racism against under the current conservative anti-immigration administration. Policy considerations generated by interviewees and organizations that are currently working to address these issues were discussed. Further work should be done to determine how refugees can be supported. The recommendations resulting from this study are increased resources towards refugee housing stability and affordability at the municipal, regional and federal level.

Key Words: gentrification, refugees, displacement, racism, demographics, sense of place, belonging 


\section{Acknowledgements}

The author of this study would like to thank everyone who supported the project and spent time coordinating and assisting the interviews conducted at the Immigrant Refugee Community Organization (IRCO), as well as Catholic Charities. Both organizations additionally supported this study through allowing the use of their space for the interviews. The study would not have been possible without the initial awareness of the topic being brought to the attention of the author by a speech given by Djimet Dogo at a United Nations Day: Global Goals, Local Leaders event hosted by the Greater Portland Sustainability Education Network and the United Nations Association of Portland held at IRCO in October 2017.

Additional thanks to thesis advisor Hunter Shobe and those who helped to edit this thesis including Madison Hathaway, Iman Chatila, Tyler Wilson, Hannah Lowe, River Wyatt-Marsh, Leslie Dressel and Anne Delessio Parson. 


\section{TABLE OF CONTENTS}

Abstract..................................................................................

Acknowledgements.............................................................

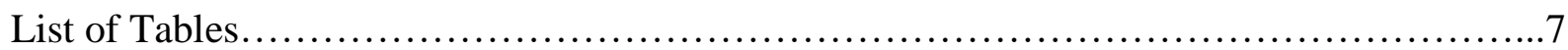

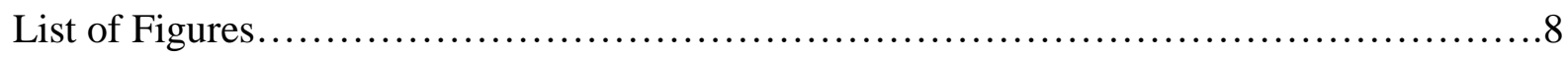

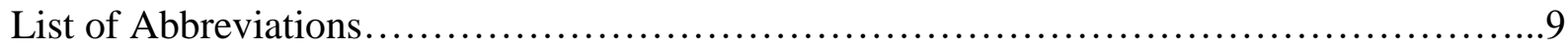

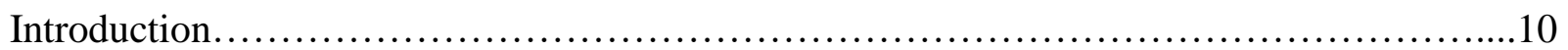

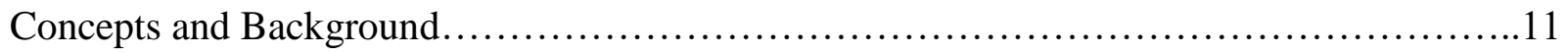

Gentrification, Displacement and Community Displacement Defined................11

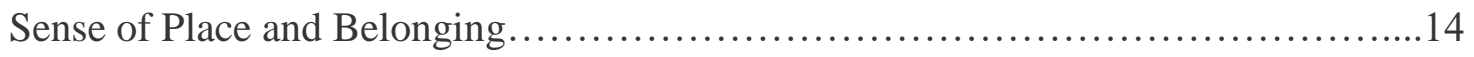

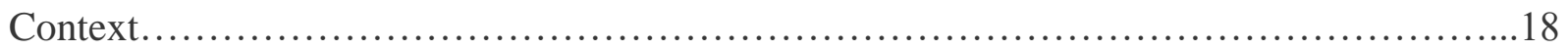

Refugees in the United States.............................................. 18

Refugees in Oregon........................................................21

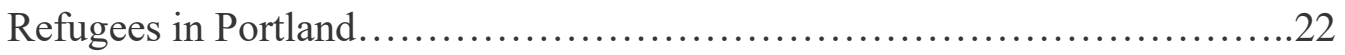

Inequitable Living Conditions for Communities of Color in Portland..................25

Housing Policy and Discriminatory Practices in Portland....................27

Local Programs and Organizations that Assist Refugees ..........................32

Previous Research Refugees Affected by Relocation............................. 35

Vulnerability of Refugees............................................... 38

Additional Barriers to Financial Success........................................39

Methods........................................................................40

Supportive Literature ................................................40

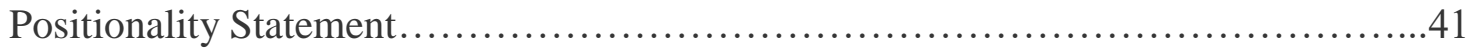


Interview Process.......................................................41

Identities of Interviewees................................................ 42

Data: Sense of Place and Belonging in Portland, Oregon.................................45

Geographic Distribution of Interviewees.....................................45

Negative Refugee Perceptions and Experiences of Portland, Oregon..................45

Rising Rental Prices...............................................45

Racism and Discrimination............................................ 45

Positive Refugee Perceptions and Experiences of Portland, Oregon....................51

Friendly, Progressive, Small and Safe..................................51

Natural Amenities.....................................................51

The Identified Importance of IRCO and other cultural services. .....................52

The Role of Catholic Charities...............................................53

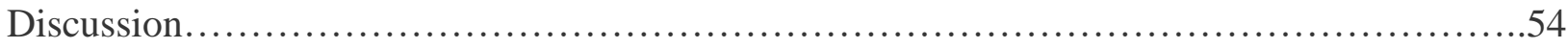

Attachment to Place..................................................................

Role of Community and Migration Networks.....................................55

Interviewees Suggestions for Addressing Rental Cost Problems.....................57

Current Affordable Housing Initiatives in Portland..............................59

Racism and its Effects on Refugees' Experiences of Portland......................66

Migration Networks..................................................... 70

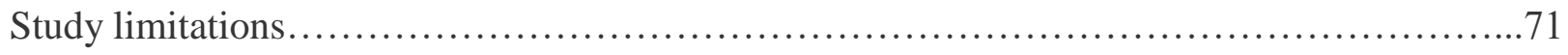

Slavic refugee differentiation/exclusion from study............................ 71

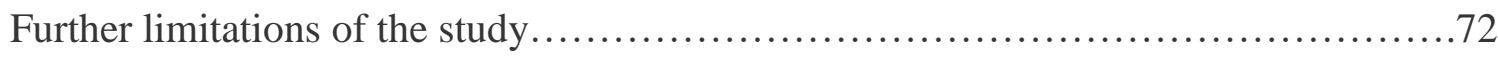

Conclusion: Action Items to Alleviate Refugee Stress................................ 72 


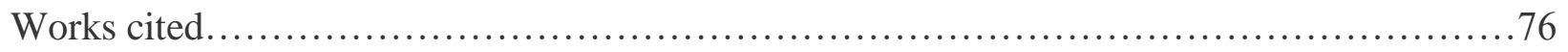

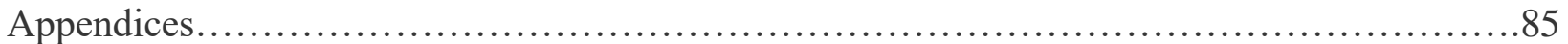

Appendix a. Glossary.................................................... 85

Appendix b. Interview Questions.............................................. 86

Appendix c. East Portland Action Plan Action Item Recommendations................90 


\section{List of Tables}

1. Living Cully's Definitions of Gentrification, Displacement and Their Relationships......13

2. Definition of Refugees and Asylees......................................... 17

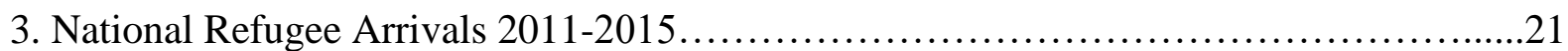

4. Community Verified Counts Methods...........................................25

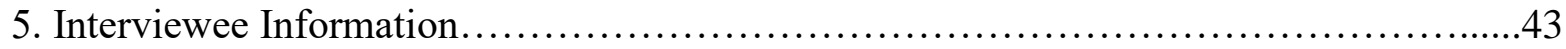




\section{List of Figures}

1. Refugee Ceiling and Arrivals for the United States 1980-2017.....................20

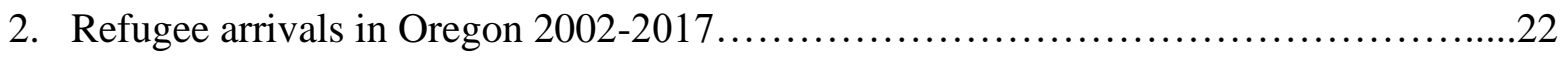

3. Portland Metro Area Refugee Resettlement 1989- 2001...........................24

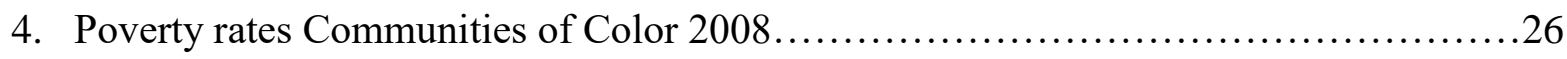

5. Change in Income and Home Prices, Portland Metropolitan Area 2006-2015............27

6. Percent Change of Populations of Color in Portland 2000-2010.....................29

7. Portland metropolitan Area Neighborhood Rental Increase 2011- 2015..............31

8. IRCO Refugees Countries of Origin........................................... 33

9. Percentage of Community Moved (White and African), 2007-2008.................36

10. Percent Paying More Than Thirty Percent on Housing,Mult. Co., 2008................37

11. Number of Times that African Refugees and Immigrants Had to Move 2010-2011....38

12. Economic Situations of African Immigrants and Refugees, Mult. Co., 2011.........40

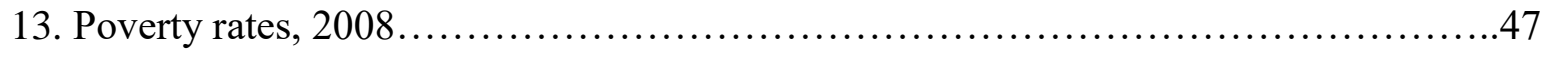

14. The Effects of Gentrification on Portland's Refugees............................55

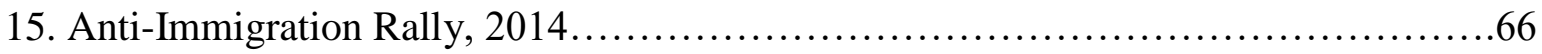

16. National Hate Crime Motivation............................................67

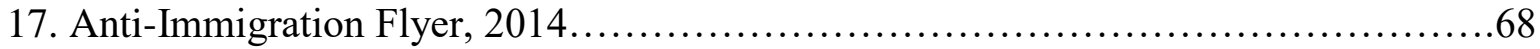

18. Anti-Semitic Graffiti (Vera Wants Affordable Housing)........................................69

19. Portland Refugee Community Member's Interview Generated Solutions...............74 
Refugees of Color Navigate Gentrification and Racism in Portland, Oregon

\section{List of Abbreviations}

CBA Community Benefits Analysis

EPAP East Portland Action Plan

EPNO East Portland Neighborhood Office

ESL English as a Second Language

JCE Just Cause Eviction

NPI Neighborhood Project Initiative

MHT Mobile Housing Team

PTSD Post Traumatic Stress Disorder

IRCO Immigrant Refugee Community Organization

SUN Schools Uniting Neighborhoods

TANF Temporary Assistance for Needy Families

TOD Commercial Transit Oriented Development

UNHCR United Nations High Commissioner for Refugees 


\section{INTRODUCTION}

Scholars have separately examined topics regarding refugee relocation and the effects of gentrification, but research regarding the specific effects of gentrification on refugees is limited. Studies that have examined refugees sense of belonging in their newly established residences are often focused on youth and do not account for human geography's theory of having a "sense of place" (Brar-Josan, 2015). The important relationship between sense of place and belonging is both psychological and political. What factors shape the ability for groups to feel and claim they belong within a place?

Limited but noteworthy news coverage has discussed the increasing impacts of gentrification on refugees residential patterns in Portland. In December 2015, the Immigrant Refugee and Community Center posted a link to a news article, that was subtitled 'Immigrant Families Replaced by Gentrification'; the link went to an article that described how populations across Portland, Oregon are becoming displaced to East Portland, an area that is known for having poor infrastructure, lack of amenities and services (Steele, 2015). In 2016, an article in The Oregonian described more in-depth that refugees are particularly vulnerable to rising rental prices, and Portland's current speed of gentrification is further displacing refugees. It was shown that some refugees moved to cheaper cities both in and outside of Oregon due to the rising rental prices (Mayfield, 2016). One of the primary issues associated with the rising rents that was highlighted was the non-fluid nature of the funds that were given to refugees (at an average of \$339 per person), despite changes in the economy (Lami, personal communication, May 14, 2018). This research highlights the emotional and physical impacts that rising rents are having on refugees by looking at the main factors that shape their perception of Portland (or sense of 
place). A central theme that emerged was the impact of racism on refugees and how it relates to displacement caused by gentrification.

Maslow's hierarchy of needs establishes the importance of safety and its relation to belonging (see Appendix A) (Brar-Josan, 2015). This study examines the ways in which housing and racism affect refugee's experience of Portland. If stability of housing is assumed to relate to belonging, then can refugees truly feel that they belong in a place without accessible housing stability? In this study, leaders active in refugee communities were interviewed to establish an understanding of their experiences, the issues they face, how their perception of Portland is altered by rising rental prices and the solutions they identify. The research aimed to help create a foundation for understanding how refugees of color's sense of place is affected by gentrification in Portland, Oregon.

The article begins with concepts and backgrounds and situates the study within broader theories and policy mechanisms before showing how they are active and influencing the lives of refugees in Portland. The article proceeds to describe the methodology used for interviewing people in refugee communities in Portland with the goal of finding more information about their experiences in Portland. The data from the six interviews is then analyzed and discussed in the context of local initiatives and examples occurring within Portland and how they relate to the solutions identified by the interviewees.

\section{CONCEPTS AND BACKGROUND}

\section{Gentrification, Displacement and Community Displacement Defined}

Gentrification occurs in instances where a neighborhood has appealing qualities that had not been previously capitalized on (with the initial rental prices and mortgages low, often times due to historic disinvestment by the government and private businesses). The process of 
gentrification occurs after the appealing qualities of a neighborhood are noticed by investors who capitalize on the opportunity to improve and make money on the properties, and people who can pay more to rent or own the properties in the neighborhood (Bates, 2013). Despite different descriptions of the process across literature, Bates emphasizes that the three common characteristics of gentrification in the literature are "housing market changes, economic status changes, and demographic changes in a neighborhood that alter its character (2013, p.9)". It is vital to understand the political nature of gentrification and the implication of said demographic changes, which can become essentially forced in economic terms. The displacement caused by gentrification differentiates it from merely being considering neighborhood revitalization, though gentrification has often been miscommunicated in that way (Bates, 2013).

This study emphasizes the use of Portland-based created definitions of gentrification by examining the Karel Gibson's 'Bleeding Albina' scholarly definition and local neighborhood advocacy group Living Cully's definition (see Table 1). Both emphasize the ways in which gentrification is "not just a matter of individually centrally located neighborhoods; it is a matter of financial and governmental decisions" (Gibson, 2007, p. 5). Living Cully's definition further demonstrates how gentrification is not only a process that is created by reinvestment and shaping of a neighborhood by institutions, rather than individual actions, but also the ways in which it affects communities, rather than individuals. Both Gibson and Living Cully also posit the ways in which economic and social inequalities are reinforced within the process of gentrification, with Gibson emphasizing the ways in which housing can be seen as the most common form of wealth (2007, p. 5). When social inequalities are reinforced, gentrification can be viewed as a tool and tactic of racism, as illustrated by the following quote by Charles Ford, who lived in a 
Portland neighborhood from 1951 onwards that was gentrified “...It's like the revitalization of racism" (Gibson, 2007, p. 19).

Table 1. Living Cully's Definitions of Gentrification, Displacement and Their Relationships.

\section{Living Cully's Explanation of the Relationship Between Gentrification, Displacement and Community Displacement}

"The term gentrification has different meanings for different people. It often provokes strong feelings of fear, loss, concern, and anger, but can also connote the many positive impacts that come with greater investment. In general terms, gentrification is the process of neighborhood change that occurs when an undervalued neighborhood becomes more desirable. This includes an influx of more affluent households, increased investment in the built environment, and a rise in housing prices. Displacement is one potential consequence of gentrification. It refers to external factors that cause people to leave the neighborhood they currently live in, for reasons that are both voluntary and involuntary.

Gentrification and displacement are two processes of neighborhood change, but there are others. These include revitalization and reinvestment, which are efforts to enhance the physical or social components of a neighborhood, often through an increased flow of capital to fund improvements. It is possible to improve neighborhoods without widespread displacement of current residents. However, historic patterns suggest that long-term disinvestment followed by renewed investment often leads to displacement of low-income residents and communities of color (Living Cully 2013, p.10).”

"Community displacement occurs when residents feel a loss of community, causing them to leave the neighborhood. This can include family and friends leaving, new stores for other clientele replacing the businesses where they shopped, or changes in public facilities or support services that they utilized (Living Cully, 2013, p.13.)"

Note: Self-created. Information obtained from Living Cully, 2013.

In a study on gentrification and displacement commissioned by the City of Portland, Bureau of Planning and Sustainability, it was emphasized that gentrification not only affects community and social dynamics, but also can lead to a loss of wealth, assets and access to services. In turn, these losses can be shown to have an economic impact on the city, causing geographic differences between where people work and live, a strain on schools and other costs related to health (Bates, 2013). Disparities of wealth and resource accessibility between white people and people of color are shown nationally and within Portland (Curry-Stevens \& Coalition of Communities of Color, 2010). 


\section{Sense of Place and Belonging: What Does it Mean and How Does it Relate to}

\section{Gentrification?}

Human geographers differentiate between the meanings of "space" and "place," emphasizing that when meaning is given to a location, it is transformed into a "place." Humans construct ideas about the way that places are meant to be and be interacted with, who belongs, and who does not (Cresswell, 1996). Massey argues that places can be viewed as a compilation of stories that make that space transform into a specific or special place in our minds (1994).

Theories that examine senses of place look at the emotional ties that humans create in places, with some scholars looking at the relationship between identity and place. The identity of places are both constructed by society's assigned meaning and through the process of one's own identity construction (Tuan, 1990). Having a sense of place can be described as a way of understanding both yourself and the world (Cresswell, 2015). How does one's identity relate to their sense of place? Gillian Rose discusses different theories that frame the ways that people identify with place and how this identification should also be considered in a broader social context, looking at the social and power relations within the place the identity is formed. Rose highlights the ways in which identifying with a place can also create a form of separation between different individuals or populations, by constructing the idea that certain characteristics or people "belong" in a place and others do not (Rose, 1995). Edward Said posits the history of the construction of Orientalism as a way that Westerners have historically differentiated themselves against Muslim North Africans and people from the Near East (for a definition of Orientalism, see Appendix A). Said asserts that Orientalism reflects the fears and desires of the West more than the realities of the East. He emphasizes that Orientalism can link to a negative focus against Islamic fundamentalism, which is positioned as a threat against the West's 
Christian fundamentalism. In this way, the Orient is argued as the place that the West is contrasted against, with its vices created in order to highlight the virtues of Western countries. Orientalism is evident in migration policies of many developing countries, though not explicit (Rose, 1995). That being said, all of the people interviewed in this study can be viewed as the "other", with their skin colors, cultural upbringings, and countries of origin different from the majority of Portland (which is $77.7 \%$ white) (U.S. Census Bureau, 2016). Sense of place can be viewed as a politics of identity (Rose, 1995).

One of the cultural explanations given for a sense of place is that senses of place are the ways in which we culturally interpret the world around us. As previously discussed, senses of place can be used to established differences between different groups and populations. Within this context, it is important to observe that different groups have more power in establishing their senses of place. Negative senses of place may be characterized by uneven social relations. This is important to note in the context of Portland, in a primarily white city, where gentrification and racial dynamics can provide concrete evidence for the types of power that are experienced in a landscape.

Senses of place amongst different social groups can be linked to historical and ongoing social processes including colonization and imperialism (Rose, 1995). With globalization, the migration of more people into different cultures may be perceived as a mounting threat to some groups who are defensive of their sense of place and the power that their group holds within their locations. This fear of globalization is also a fear of fluidity of spaces; with a greater number of migrants, come larger and more complicated definitions of place (Massey, 1994). Robert Sack describes this as territoriality, noting that it " is a primary geographic expression of social power." He situates the importance of territoriality by claiming that, "It is the means by which 
society and space are related (Rose,1995, p. 100).” This argument can be seen as related to gentrification, as different groups are pushed out in order for new people to lay claim in new spaces. Though the incoming group may not recognize the power or privilege that they hold, the power of their social identities is evident to those who are being forced out of the neighborhood, and no longer able to claim it as their own "territory". Gentrification can be viewed as a process that allows one group's definition of a sense of place to eclipse another's. Rose discusses the ways in which senses of place become "more intense", the more they are felt as "under threat" (1995, p.97). As evidenced by Said's theories of Orientalism and the construction of "the Other", people's emotional reactions to place can greatly affect how they view and interact with others.

Portland is an interesting place to study these dynamics given its reputation as a liberal and welcoming city, despite its location in a state that is conservative in most regions (HaiderMarkel et al., 2009). Portlanders have been known for telling people to "go back to California" among other exchanges that pose that certain groups do not belong in the city, and may be seen as contributing to or causing the problem of rising rental prices (Perry, 2017). This study may identify ways in which the rhetoric towards refugees and those who have come from greater distances and cultural differences (that may be evidenced to someone who interacts with them based on their skin color, accent, clothing, mannerisms, etc.) may be even more extreme. On a national level, the rhetoric of creating and working against the incorporation of "the Other" into the United States societies is certainly seen in President Donald Trump's "Make America Great Again" rhetoric.

A relevant study about refugees' integration into Canadian society used psychologyoriented theories surrounding belonging, rather than looking from the geographical lens of sense 
of place (see Appendix A for a definition of Belonging). Novjyot Brar-Josan's dissertation findings emphasize how it is important for refugees to have their basic needs met in order to develop a sense of belonging, which relates to the ways in which gentrification may affect both refugees sense of place and their sense of belonging to Portland as a place, or hopeful new "home" (2015).

Table 2. Definition of Refugees and Asylees.

\section{Forced Displacement: Refugees and Asylees Defined}

A refugee, as defined by U.S. refugee services and the 1951 convention relating to the status of refugees, is a person who "owing to a well-founded fear of being persecuted for reasons of race, religion, nationality, membership of a particular social group, or political opinion, is outside the country of his nationality, and is unable to, or owing to such fear, is unwilling to avail himself of the protection of that country." Refugees do not apply for their status on their own. The United Nations High Commission for Refugees (UNHCR) determines who is the most vulnerable to danger and opens a case for them. The definition of an asylee differs legally. An asylee is a person granted legal asylum in the United States. Their application process is different from a refugee's and it can take longer to obtain the associated services that they will receive once granted asylum, which gives them the same rights and services as a refugee (United States Committee for Refugees and Immigrants, 2007). 86\% of the world's refugees are relocated to developing countries. Refugees do not Though the number of refugees resettled worldwide dropped 50\% between 2016 and 2017, it is still important to plan for a future where more people may be subject to forced displacement due to 
environmental events, factors and other threats (United Nations High Commission for Refugees, 2018).

Note: Self-created. Information obtained from United States Committee for Refugees and Immigrants, 2007) and (United Nations High Commission for Refugees, 2018).

\section{CONTEXT}

\section{Refugees in the United States}

A currently contested political topic involves the question of how the United States government should support refugees, including what financial support should be distributed if refugees are admitted. Refugees are placed within 190 communities in 49 states after their arrival (United States Department of State, 2018). The geographical distribution of refugee resettlement is determined within weekly meetings where representatives from resettlement agencies look at factors such as what resources are available within a community and how they match a refugee's needs. If a refugee has a family member in the United States, they are more likely to be resettled near that family member. The most common state for refugees to be resettled is California, followed by Texas (United Nations High Commissioner for Refugees, 2018).

The U.S. government currently has agreements with nine domestic agencies that are tasked with resettling refugees. Though some of these organizations are religiously affiliated, they are not allowed to promote their religions to incoming refugees (United States Department of State, 2018). Once a destination for refugee resettlement is selected, refugees are transported to this destination. The transportation costs of refugee resettlement are expected to be paid back by the refugee once they are established in their new community. The Department of State's Reception and Placement program assists refugees for the first three months they are in the country. They provide resettlement agencies with a one-time sum that can be used to assist with 
meeting expenses for refugees during their first few months in the country. This fee is often used to assist refugees in their survival needs including housing costs, food, furnishings, and clothing. Other than providing for the basic needs of refugees directly, the money can also be used for the resettlement organization's financial needs including salaries for the employees, office space and other finances that come with their resettlement work (United States Department of State, 2018).

Refugees receive employment authorization upon arrival. Research suggests that the quicker that refugees find employment, the easier it will be for them to learn English. After one year in the United States, refugees are required to apply for permanent residence (often referred to as a green card) and after five years, a refugee is eligible to apply for U.S. citizenship (United States Department of State, 2018).

Between World War II and the Obama Administration, the United States was known as a world leader in refugee resettlement (Lind, 2017). However, in 2017 the United States admitted the smallest number of refugees since 2002. Upon taking office, President Donald Trump set an annual cap of admitting no more than 45,000 refugees per year. This is the lowest refugee admittance cap since the creation of the Refugee Resettlement Program in 1980 (Gomez, 2018) (see Figure 1). Trump's executive order to bar citizens of 11 countries included half of the largest groups of refugee immigration into the United States in 2017, including those from Egypt, Iran, Iraq, Libya, Mali, North Korea, Somalia, Sudan, South Sudan, Syria and Yemen (Gomez, 2018). In December of 2017, the United States announced that the country would be withdrawing from the Global Compact on Migration (United States Mission to the United Nations, 2017). 


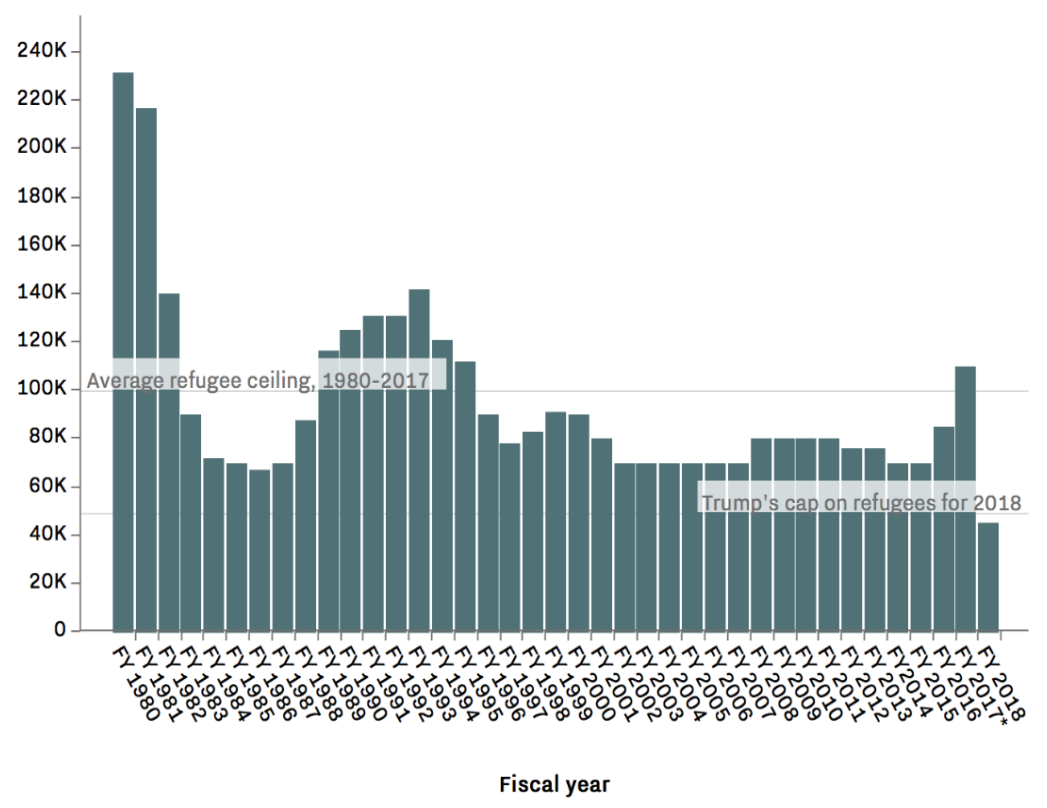

Figure 1. Refugee Ceiling for the United States 1980-2017.Average refugee ceiling and actual refugee ceiling, indicated for each year. Reproduced from by Lind, D. Data sources compiled by Dara Lind from the Migration Institute (for data prior to 2004 and the State Department and the Department of Homeland Security (for data occurring after 2014).

How do refugees fare economically after they arrive? In $2015,47.4 \%$ of refugees in the US who had arrived within the last year were employed. The overall unemployment rate for refugees was $18.8 \%$. Women were particularly affected and experienced a $27 \%$ unemployment rate (Office of Refugee Resettlement, 2015, p. 25). Refugees that have been in the United States for a year or more experience significantly higher rates of employment than those who have been in the United States for less than one year. Of the refugees that were surveyed, $10.3 \%$ did not seek employment due to their lack of English skills (Office of Refugee Resettlement, 2015, p.27). 
Table 3. National Refugee arrivals from 2011-2015. Data collected in 2015. Refugees had the lowest hourly wage, lowest home ownership and high rental rates (at 93.8\%) during the year 2015.

\begin{tabular}{|lllllll|}
\hline & $\begin{array}{l}\text { HOURLY WAGES } \\
\text { OF EMPLOYED } \\
\text { CURRENT JOB }\end{array}$ & $\begin{array}{l}\text { OWN HOME OR } \\
\text { APARTMENT }\end{array}$ & $\begin{array}{l}\text { RENT HOME OR } \\
\text { APARTMENT }\end{array}$ & $\begin{array}{l}\text { PUBLIC ASSIS- } \\
\text { TANCE ONLY }\end{array}$ & $\begin{array}{l}\text { BOTH PUBLIC } \\
\text { ASSISTANCE \& } \\
\text { EARNINGS }\end{array}$ & $\begin{array}{l}\text { EARNINGS } \\
\text { ONLY }\end{array}$ \\
\hline ARRIVAL COHORT & $\$ 10.86$ & $8.4 \%$ & $90.5 \%$ & $5.2 \%$ & $23.8 \%$ & $70.1 \%$ \\
2011 & $\$ 10.58$ & 6.9 & 92.5 & 7.9 & 31.3 & 56.8 \\
2012 & $\$ 10.49$ & 5.6 & 93.4 & 6.3 & 34.1 & 57.8 \\
2013 & $\$ 10.39$ & 1.5 & 96.1 & 7.7 & 32.2 & 58.5 \\
2014 & $\$ 10.22$ & 2.2 & 95.8 & 10.0 & 62.5 & 26.0 \\
Total Sample & $\mathbf{\$ 1 0 . 5 2}$ & $\mathbf{4 . 7}$ & $\mathbf{9 3 . 8}$ & $\mathbf{7 . 4}$ & $\mathbf{3 7 . 3}$ & $\mathbf{5 3 . 4}$ \\
\hline
\end{tabular}

Reproduced from the Office of Refugee Resettlement, 2015.

Refugees in Oregon. According to the Oregon Department of Human Services, 65,832 refugees currently live in Oregon (2016). In the year 2016, Oregon allowed 1,780 to move into the state, the largest number in almost twenty years. The largest influx of refugees per year was in 1980 when over 6,000 refugees entered the state. The refugee population in Oregon represents only a small fraction of the general population of 4.143 million people. The majority of incoming refugees arrive and initially settle into Portland (Oregon Department of Human Services, 2018). The number of refugees resettling in Portland has decreased approximately 50 percent under the Trump administration. The approximate number of refugees who enter Oregon were set to drop from 2016's admittance of 1,780 individuals to around 750 (Sparling, 2017) (see Figure 2). 


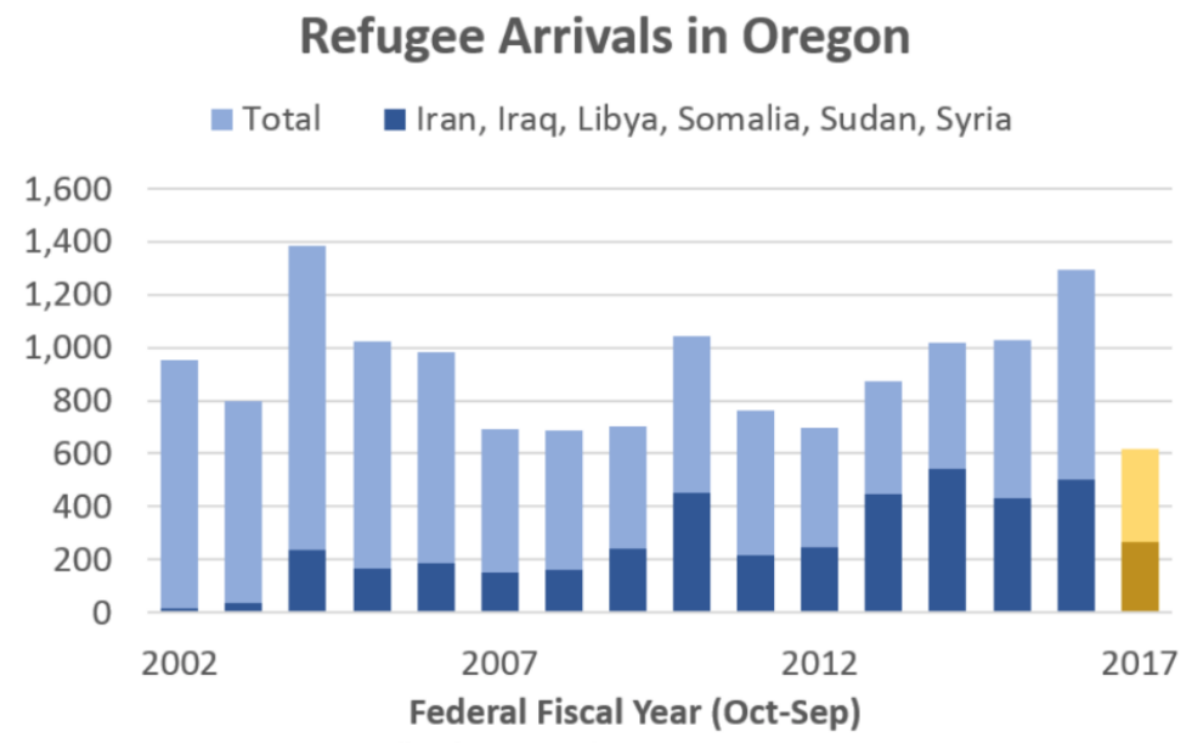

Figure 2. Refugee arrivals in Oregon 2002-2017. Emphasis on the percentage of Middle

Eastern and African refugees fraction of the total arrivals. Reproduced from Oregon Office of Economic Analysis. Data source U.S. State Department, Oregon Office of Economic Analysis.

The most common refugee groups arriving in Oregon are from, Cuba, Burma, Bhutan, Iran, Iraq, and Somalia (Oregon Department of Human Services, 2018). The largest group of refugees in Oregon are from the former Soviet Union. Oregon is the only state in the U.S. where Russia is the third greatest language spoken. Approximately 100,000 people in Oregon have been identified as a part of the "Soviet diaspora" (Greenstone, 2016). Between 1990 and 2005, Oregon and Washington admitted more Russian and Ukrainian immigrants than any other part of the country (Hardwick, 2009).

Refugees in Portland. Portland has been identified as a "re-emerging immigrant gateway" (Hardwick and Meacham, 2014). From 1990 to 2000 Portland's growth rates of foreign-born people were double that of the nation, with an overall $136.3 \%$ raise in the foreignborn population in four decades. Between 1983 and 2004, Portland was ranked as the 12th most popular city for refugee resettlement in the United States, with the majority of refugees from 
Eastern Europe, Africa, and Southeast Asia. Refugees from Sub-Saharan African countries began arriving in large numbers in Portland in the 1980s in response to wars (Hardwick and Meacham, 2014).

Research has shown that refugees who are resettled in Portland face cultural and financial stressors (Boise et al., 2013). Refugees who are resettled in Oregon receive eight-months of financial and medical assistance in exchange for their attendance at language and skill sessions at Immigrant Refugee and Community Organization (Oregon Department of Human Services, 2018). Coming from diverse countries, circumstances and cultural differences, the settlement of refugees and their experiences can be largely affected by the communities they are settled within.

The largest nonprofit in Oregon is the Immigrant Community Refugee Organization (IRCO). In 2000 more than 90 percent newly arriving refugees decided to live in neighborhoods surrounding IRCO citing the support of IRCO as the primary reason for this geographic distribution (Hardwick \& Meacham, 2005, p. 554). See figure 3 for a visual for refugee housing distribution between 1989 and 2001. 

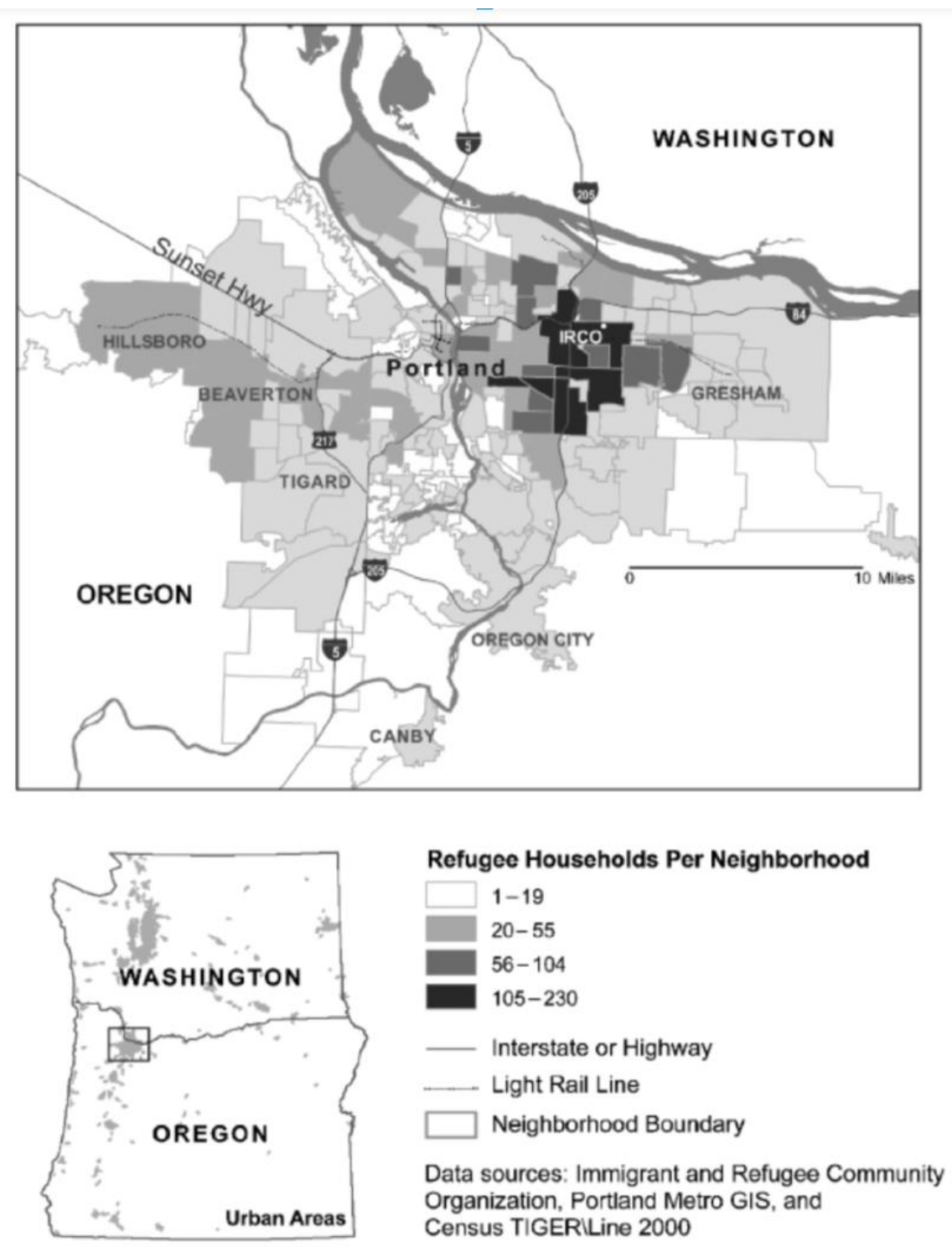

Figure 3. Portland Metro Area Refugee Resettlement 1989- 2001. Reproduced from Hardwick \& Meacham, 2005.

Between 2012 and 2016, the number of foreign born people in Portland were $13.6 \%$ of the population (Oregon Office of Economic Analysis, 2017). Curry-Stevens \& Coalition of Communities of Color emphasizes that many communities of color are undercounted and misrepresented in the census (see Table 4). They have formulated a process for determining Community Verified Counts (2014). It is important to note the actual composition of Portland 
communities in determining the need for services. The inaccurate and undercounted nature of many statistics regarding race in Portland show the ways in which this data is difficult to obtain, making the issue of affordable housing for these populations harder to address.

Table 4. Community Verified Counts Methods. Data displaying showing the ways in which communities are misrepresented (and often underrepresented) in statistics.

\begin{tabular}{|c|c|c|c|c|c|c|c|}
\hline & $\begin{array}{c}\text { ACS } \\
\text { count } \\
(2010)\end{array}$ & $\begin{array}{l}\text { Oregon's } \\
\text { Refugee } \\
\text { Program }\end{array}$ & $\begin{array}{c}\% \text { of Oregon's } \\
\text { population } \\
\text { that lives in } \\
\text { Multnomah }\end{array}$ & $\begin{array}{l}\text { Community } \\
\text { Count in } \\
\text { Multnomah } \\
\text { County }\end{array}$ & $\begin{array}{l}\text { Undercount } \\
\text { (in \#) }\end{array}$ & $\begin{array}{l}\text { Undercount } \\
\text { (in \%) }\end{array}$ & Qualifiers \\
\hline $\begin{array}{l}\text { Asian } \\
\text { Indian }\end{array}$ & 3,509 & & & 1736 & $-1,773$ & $-102.1 \%$ & No undercount \\
\hline Bhutanese & 190 & 209 & N/A & & 19 & $9.1 \%$ & $\begin{array}{l}\text { Presumed all live in } \\
\text { Multnomah and no } \\
\text { migration or births }\end{array}$ \\
\hline Burmese & 792 & & $\mathrm{~N} / \mathrm{A}$ & 1550 & 758 & $48.9 \%$ & no migration or births \\
\hline Cambodian & 1,248 & 3,474 & $37.1 \%$ & 1289 & 41 & $3.2 \%$ & no migration or births \\
\hline Hmong & 1,674 & & & 2250 & 576 & $25.6 \%$ & \\
\hline Laotian & 3,392 & 5,799 & $52.8 \%$ & 3062 & -330 & $-10.8 \%$ & $\begin{array}{l}\text { No undercount \& no } \\
\text { migration or births }\end{array}$ \\
\hline Thai & 1,110 & & & 2,000 & 890 & $44.5 \%$ & \\
\hline Vietnamese & 15,270 & 16,946 & $43.7 \%$ & 7677 & & $0.0 \%$ & no migration or births \\
\hline Iraqi & & 438 & N/A & 750 & 312 & $41.6 \%$ & \\
\hline Tongan & 551 & & & 1200 & 649 & $54.1 \%$ & \\
\hline \multicolumn{6}{|c|}{ Average Undercount of these Estimates } & $11.4 \%$ & \\
\hline
\end{tabular}

Note: Reproduced from Curry-Stevens and Coalitions of Communities of Color (2010).

\section{Inequitable Living Conditions for Communities of Color in Portland, Oregon}

This study will be focused on Asian, African and Middle Eastern refugees. It is important to understand the disparities they are facing within the local context of their broader communities. Five identified communities of color in Portland disparities were found to have been worse than National Outcomes (of child poverty, number of people who get a university degree, annual income, occupation and renters paying $30 \%$ more for their rent) and worse than in Seattle (specifically in King County) (Curry-Stevens \& and Coalition of Communities of Color, 2010,p. 9). 
Portland has been highlighted in the national news for the racist past that is often not talked about when the appeal of Portland's progressive nature is highlighted (Semuels, 2016). It is important to acknowledge the economic barriers that people of color face in Portland, with the average person of color making over 8,000 dollars less than a white person in the same county. The average unemployment rate for a person of color in Portland is $76 \%$ worse than for a white person. White communities typically have incomes $124 \%$ higher than communities of color, with the overall poverty rate of communities of color at $26.7 \%$ in the year (Curry-Stevens \& Coalition of Communities of Color, 2014) (see Figure 4).

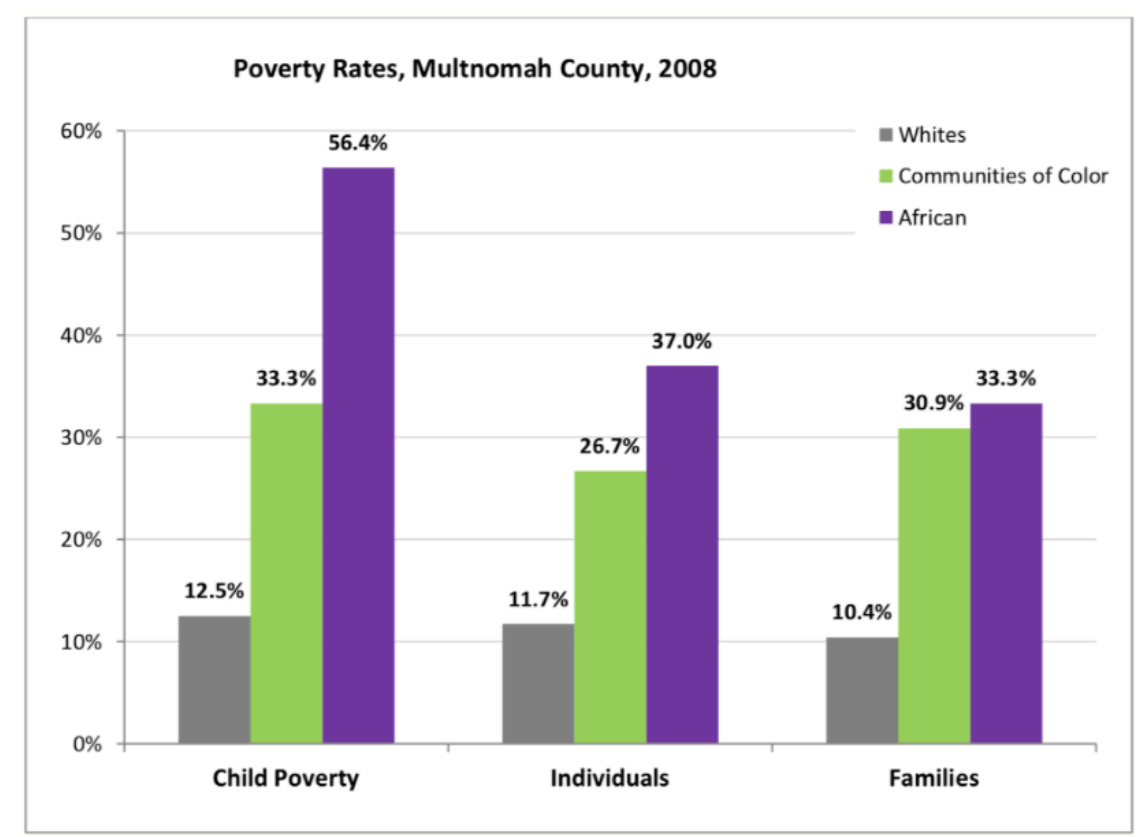

Figure 4. Poverty rates for Multnomah County 2008. Reproduced from Curry-Stevens 2014, data taken from Population Research Center, Portland State University, American Community Survey, 2008.

Weight should be given to the fact that some refugees in Portland face additional barriers when they are both black and Muslim, with Somali refugees being the largest Muslim and largest black immigrant communities in Oregon (Bashir, Muse \& Curry-Stevens, 2016). 


\section{A Brief History of Housing Policy and Discriminatory Practices in Portland,}

Oregon. Portland was identified as the fourth fastest gentrifying city in the United States (Pan, 2017). In 2010, close to one-quarter of Portland's renters were spending more than half of their income on housing and transportation (City of Portland, 2016, GP5-1). It is estimated that population and other pressures will cause 25 to 30 percent of Portland residents to fall into this category (City of Portland, 2016, P. GP5-9). The high demand for affordable housing in Portland is evidenced by Figure five, which illustrates the gap between housing costs in percentage increase and income in percentage of increase between 2006-2015. It is shown that apartment rent increased $63 \%$ whereas renter income only increased $39 \%$.

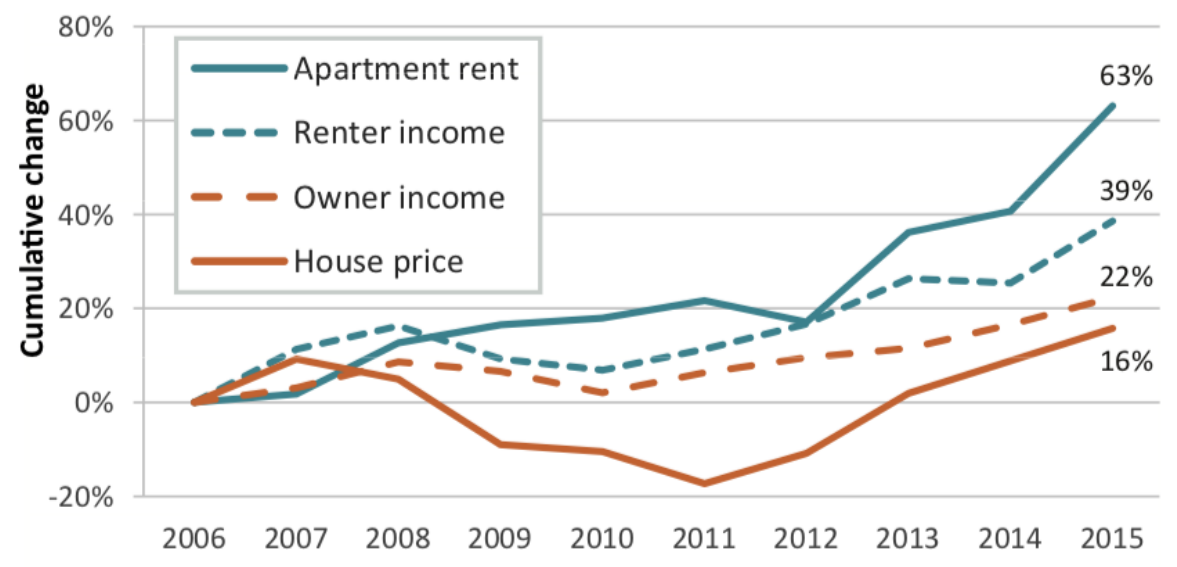

Figure 5. Change in Income and Home Prices, Portland Metropolitan Area 2006-2015. Cumulative change in apartment rent, house price, renter and owner income is shown. Reproduced from Metro, 2016. Data from Multifamily NW, RMLS, U.S. Census Bureau, Johnson Economics.

Further evidence is provided by the long wait lists for section eight housing, with section eight vouchers taking six to seven years to obtain in the neighboring suburbs in Washington County and three to four years to obtain in Portland (Bashir, Muse, \& Curry-Stevens, 2016). In October 
2015, the City Council declared a housing emergency for the duration of one year (Floum, 2017).

In October 2016, the housing emergency was extended through another year. In 2016 Portland rents increased at an average of $7 \%$ or 75 dollars per month, making it the fifth year in a row where rental prices increased over 5 percent per year. This equates to a thirty percent increase in rental prices between 2012 and 2016. Studio apartments in Southwest and outer Southeast Portland have increased an average to 18 to 60 percent during this time period (Portland, Oregon, City Ordinance 188627, pg. 2, 2017). It is shown that both of these neighborhoods have also had increases in their composition of communities of color (see Figure 6). There is an emphasis on the trend that Portland populations of color are primarily shown outside of central areas of the city, with a large concentration in East Portland. 


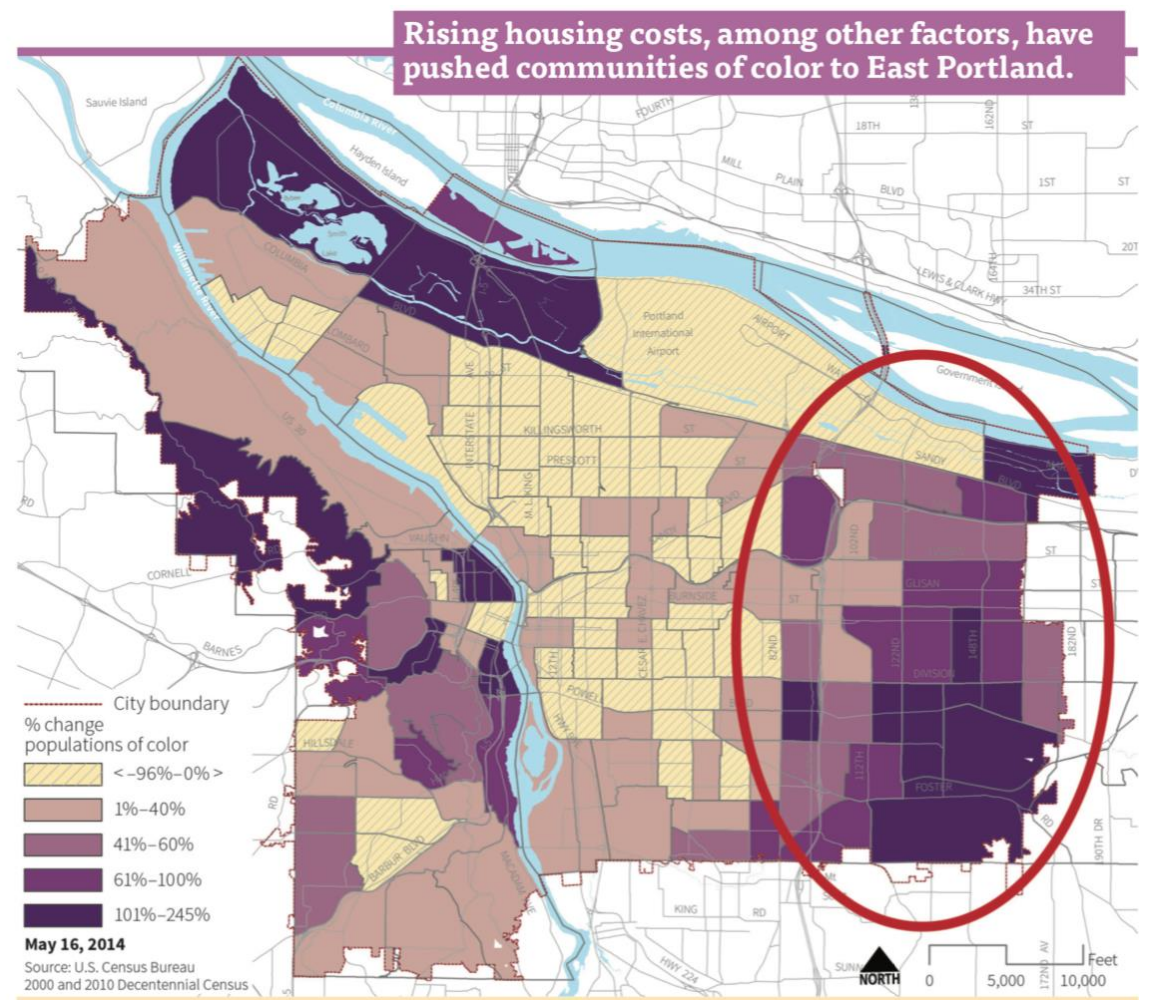

Figure 6. Percent Change of Populations of Color in Portland 2000-2010.Reproduced from the 2035 Comprehensive Plan for the City of Portland, Oregon. Data extracted from the U.S. Census Bureau for 2000 and 2010 Decennial Census.

The city notes that East Portland, North Portland and Southwest Portland are of particular concern for involuntary displacement of renters (Portland, Oregon, City Ordinance 188627, pg. 2). The state of emergency resulted in the city designating that 45 percent (rather than 30 percent) of urban renewal funds would go towards housing rather than 30 percent over the next eight year. In October 2017, the housing emergency was extended for the second time (Floum, 2017).

Gentrification has been an ongoing historical problem in Portland that has been noted for specifically pushing certain communities (primarily African American) out of previously 
affordable neighborhoods (Gibson,2007). Albina was a historically African American

neighborhood. In recent years, 10,000 of Portland's 38,000 African American residents have been pushed away from the central core of the city (Van Wing \& Greenstone, 2016). In 2005, Hardwick \& Meacham reported that many African refugees lived in inner NE neighborhoods, which are some of the most historically gentrified neighborhoods. In 2015 it was found that the neighborhoods that marginalized communities have long been pushed into now have rising rents higher than the inner neighborhoods which are typically viewed as destinations with greater amenities, infrastructure, services and proximity to business hubs (Mesh, 2015).

Another historical factor that may be contributing to current unaffordability of housing in Portland is Oregon's ban on rent control, which began after rent control was advocated for in Lane County in 1982. A three-year temporary ban was initiated in response, with those opposed justifying their actions by referencing the negative effects of rent control that was implemented during World War II. After the three years, Charlie Hales, Portland Former Mayor testified to extend the bill permanently. House Bill 2505 was passed. It is noted that there is a debate about the difference between rent control and rent stabilization. Currently, four states and the District of Columbia allow rent stabilization (Flanigan, 2017). In 2017, ORS 91.225 verified the state’s commitment to not using the tool of rent control despite the current housing emergency when stating:

The Legislative Assembly finds that there is a social and economic need to ensure an adequate supply of affordable housing for Oregonians. The Legislative Assembly also finds that the imposition of general restrictions on housing rents will disrupt an orderly housing market, increase deferred maintenance of existing housing stock, lead to an abandonment of existing rental units and create a property tax shift from rental-owned to owner-occupied housing. Therefore, the Legislative Assembly declares that the imposition of rent control on housing in the State of Oregon is a matter of statewide concern (Oregon ORS 91.225, 2017). 
The effects of gentrification are an important discussion topic due to the speed of the rate of gentrification currently in Portland, with high demand for housing evidenced in the expected growth of 123,000 households between 2010 and 2035 (City of Portland, 2016,p. GP56). For African refugees, this need is the effects of unaffordable housing are evident based on the fact that 1 in 4 Africans have to move annually, with $47 \%$ of African community members saying that they were unable to find housing that was both affordable and safe (Curry-Stevens, 2013).

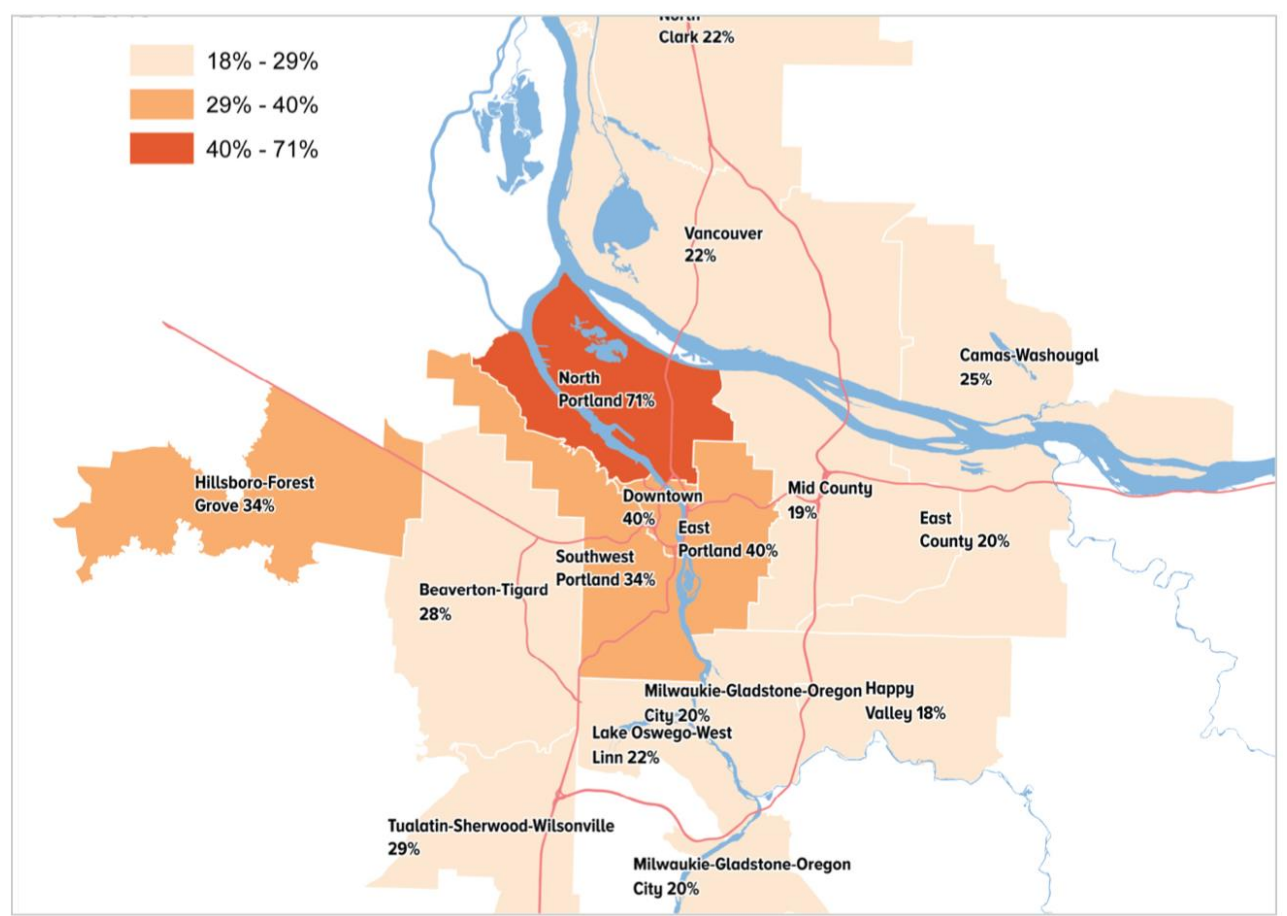

Figure 7. Portland metropolitan Area Neighborhood Rental Increase 2011 to 2015. It is shown that outlying neighborhoods, including East Portland and North Portland neighborhoods, had higher percentages of rising rents than central neighborhoods other than downtown. Reproduced from Metro,2016. Data was taken from Multifamily NW, Axiometrics Johnson Economics.

\section{Local Programs and Organizations that Assist Refugees}

Opened in 1976, "by refugees, for refugees" the Immigrant Refugee Community

Organization (IRCO) assists refugees and immigrants in SW Washington and Oregon (2018).

Identifying Oregon and Washington as some of the first states to assist refugees in their 
relocation and adjustment following political occurrences across the world in the 1970s, IRCO was started from a gathering of grassroots, culturally specific support groups that were primarily centered around Asian immigrant and refugee assistance. In 2001 IRCO became the organization that it is known as today. IRCO provides 200 culturally and linguistically specific services, with several culturally specific resource centers, including the Asian Family Center that opened in 1994 and the Africa House that opened in 2006. IRCO also has an international language bank and senior center. Over 70\% of IRCO's staff and board of directors are immigrants and refugees (Immigrant Refugee Community Organization, 2018). IRCO works with 1,000 refugees each year, placing them in over 800 jobs (Silvis, 2014). In 2017 IRCO provided services to 31,349 people in Portland, with the four largest groups assisted including Asian, African American, Latinx and African immigrant or refugees (IRCO, 2017,p. 3) (see Figure 8). 


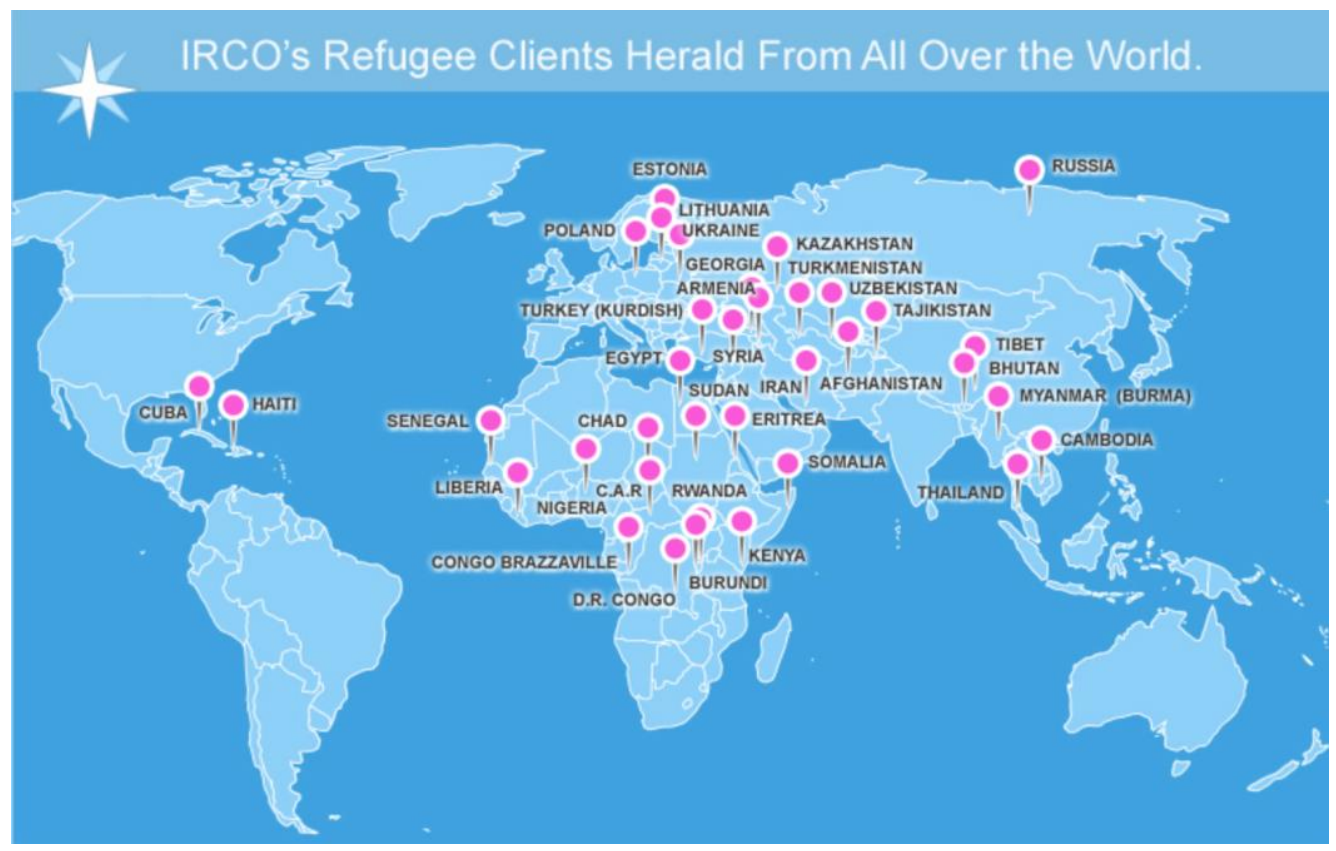

Figure 8. IRCO Refugees Countries of Origin. Reproduced from the Immigrant Refugee Community Organization, 2018.

IRCO is a member of the Coalition of Communities of Color, among other organizations that it partners with to help in advocacy for immigrant and refugee rights (Coalition of Communities of Color, 2018). IRCO helps to provide a number of services that are both culturally specific and not, with many of their rental and energy assistance services being open to Portlanders who are not immigrants or refugees. In 2017, IRCO provided energy assistance to over 6,000 people (Immigrant Refugee Community Organization, 2017,pg. 5). The Multnomah Stability Initiative (MSI) helps families with rent and case management for up to two years. Those who receive this assistance are expected to reach self-sufficiency goals in income and health, with additional attention being given to their families. Funding can go towards rent, energy assistance/bills, work related expenses, transportation and more. IRCO receives weekly updates on the progress of the client to see if they still need assistance. They then determine when a case is stable and able to be closed. The following are other specific services that were 
identified in interviews conducted in this study. Another service that IRCO provides that is related to housing affordability and assistance is Home Forward. Clients who are in the MSI program can receive rental assistance from Home Forward as well. Home Forward's short term rental program is designed for eligible participants in Multnomah County. Those who can apply are low-income clients including those with and without children, including seniors, chronically homeless and vulnerable clients, and disabled clients. IRCO also works with the Mobile Housing Team (MHT), specifically for cases where clients have children. Clients are referred to IRCO through the 211 hotline. Lastly, IRCO also provides housing assistance for students who attend Earl Boyles SUN community elementary school (anonymous IRCO Employee, personal communication, February 28, 2018). In 2017, $96 \%$ of the families that IRCO provided rental assistance for attained stable housing (IRCO, 2017, p. 9). IRCO continues to be supported by a number of public and private sources from a number of scales, including from the federal level. In 2015 IRCO was granted 165,000 by the ORR Ethnic Community Self-Help Program, which was less than the amount given in 2009 at 200,000 (Office of Refugee Resettlement, 2009, p. 49; Office of Refugee Resettlement, 2015, p. 62).

Placement agencies such as Catholic Charities also have a large role in connecting refugees to affordable housing. There has been some history of communities being placed within the same apartment complexes or areas without acknowledging historic and current tensions between those communities. After a history of enslavements of the Somali people, a resettlement agency housed Bantus migrants in the same affordable complex as the Somali community. The Bantus migrants were later relocated to Gateway, an outer northeast neighborhood where IRCO is located(Hardwick \& Meacham, 2014). In 2015 there were 1,489 cases opened with partner agencies meant to help with language skills, employment and on the drop training and fiscal 
training. Of these 1,489 refugee cases, 997 became employed by the end of the assistance period. However, only 449 terminated their cash assistance, with a low number of 25 cash reductions. 687 job retentions were recorded, with the average refugee wage for the cases being 9.96 dollars per hour. 509 health benefits were offered (Office of Refugee Resettlement, 2015).

\section{Previous Research that Relates Refugees Emotional Ties Being Affected by Relocation}

Keller examined the experiences of immigrant and refugee young adults who were relocated after living in public housing, with themes emerging about senses of place and belonging, how moving related to how the individuals felt they belonged with and felt comfortable in a community, and the role that differences in income within a community can have on shaping these feelings (2011). Keller suggested that public housing may provide a space where feelings of loss and not belonging can be mitigated through the social support of the other low-income community members in a unit. The ways in which housing instability and relocation can lead to a second feeling of loss and disconnection from belonging within a place relate to this study's examination of how instability in housing may change the way in which refugees perceive Portland. Keller summarizes these feelings in the following statement, "Residents of this community, many of whom had been uprooted from their homeland, felt an attachment to this place and feel a sense of loss as they have witnessed dramatic changes to the physical and social fabric of the community (2011, p. 158)." In the case of Portland, the connection between housing stability and "community" is drawn in the 2035 comprehensive plan where preserving community, and "rebuilding communities" are written as housing related goals (City of Portland, 2016, GP5-8).

Additionally, local and nonlocal research is drawn on for this study that looks at the life outcomes that refugees and immigrants experienced in places, and how these factors affected 
their health and wellbeing. The Coalition of Communities of Color and Curry-Stevens reports are examples of this type of literature, with housing related surveys examined and conducted during their research (see Figures 9, 10 and 11).

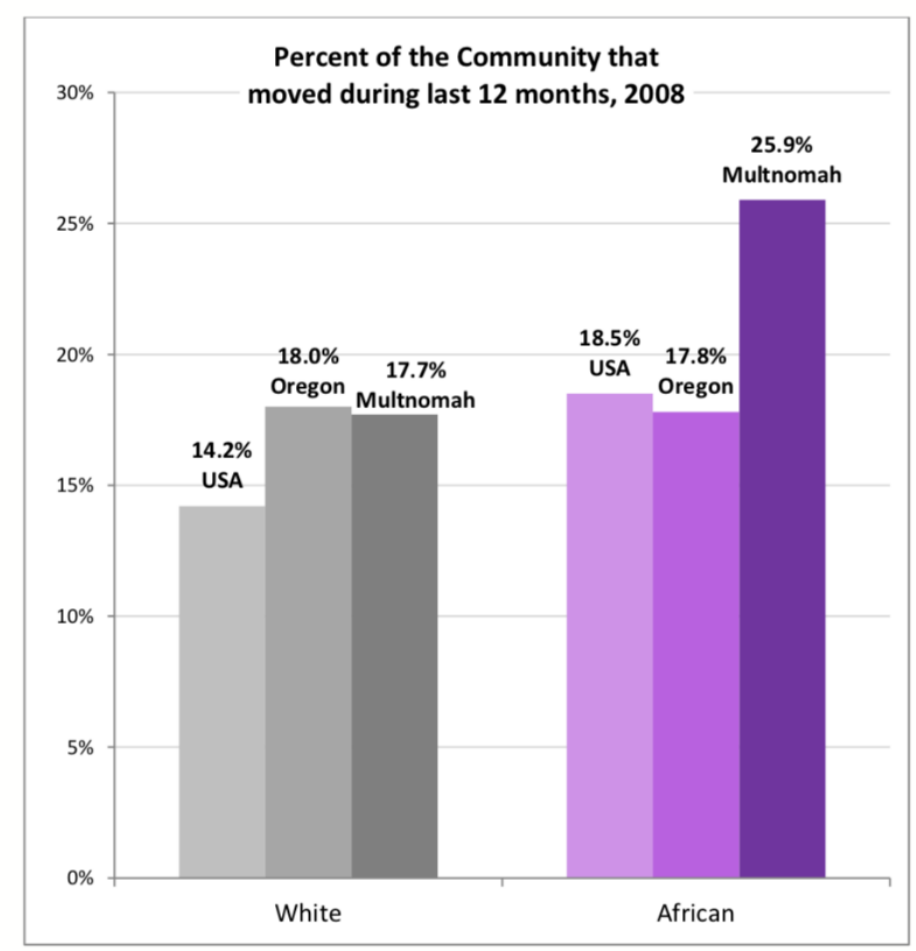

Figure 9. Percentage of Community that has moved during the last 12 months (White and African), 2008. Examined on three scales: in the United States, in Oregon and in Multnomah County. Reproduced from Curry-Stevens, 2013. Data source: Population Research Center, Portland State University, American Community Survey, 2008. 


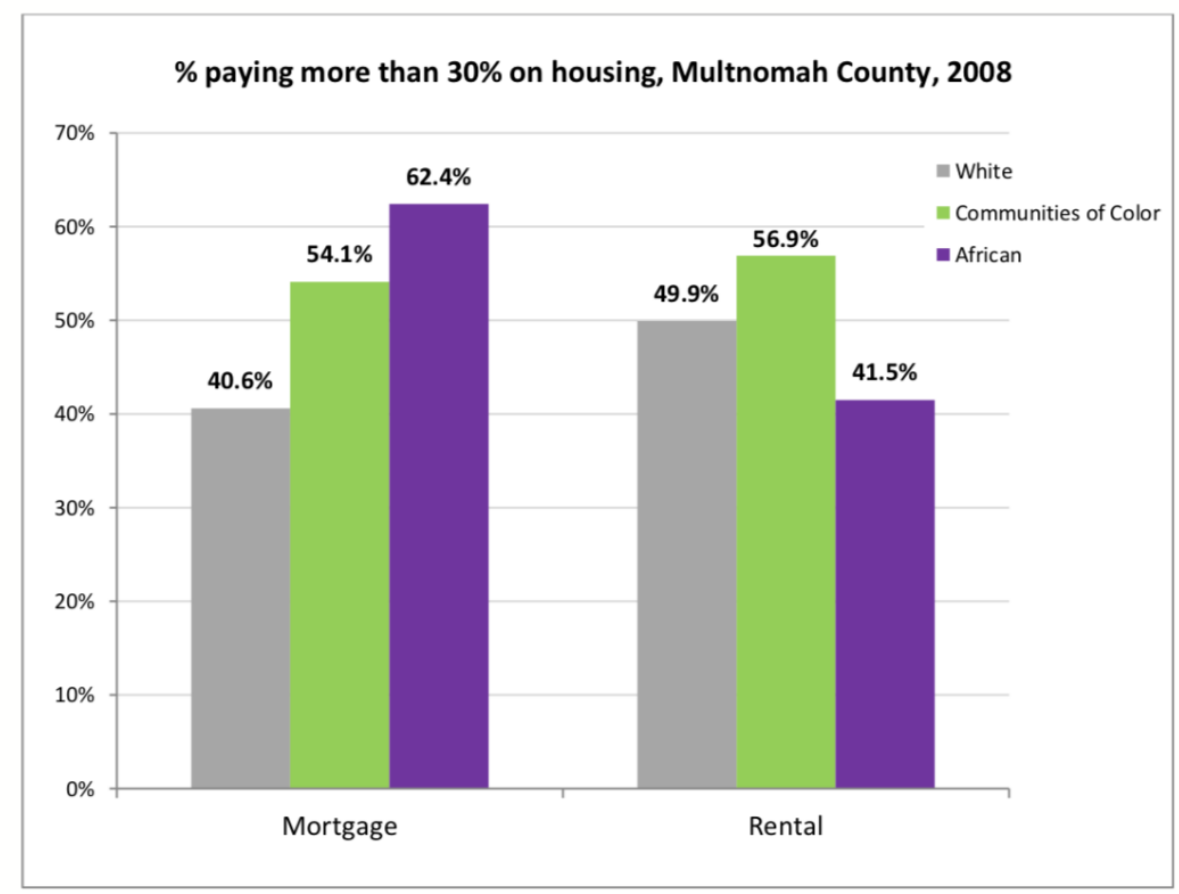

Figure 10. Percent Paying More Than Thirty Percent on Housing in Multnomah County, 2008.

The high rate of people who were paying more than thirty percent of their income on rent during the economic recession is shown. Reproduced from Curry-Stevens \& Coalition of Communities of Color, 2013. Data source Population Research Center, Portland State University. 


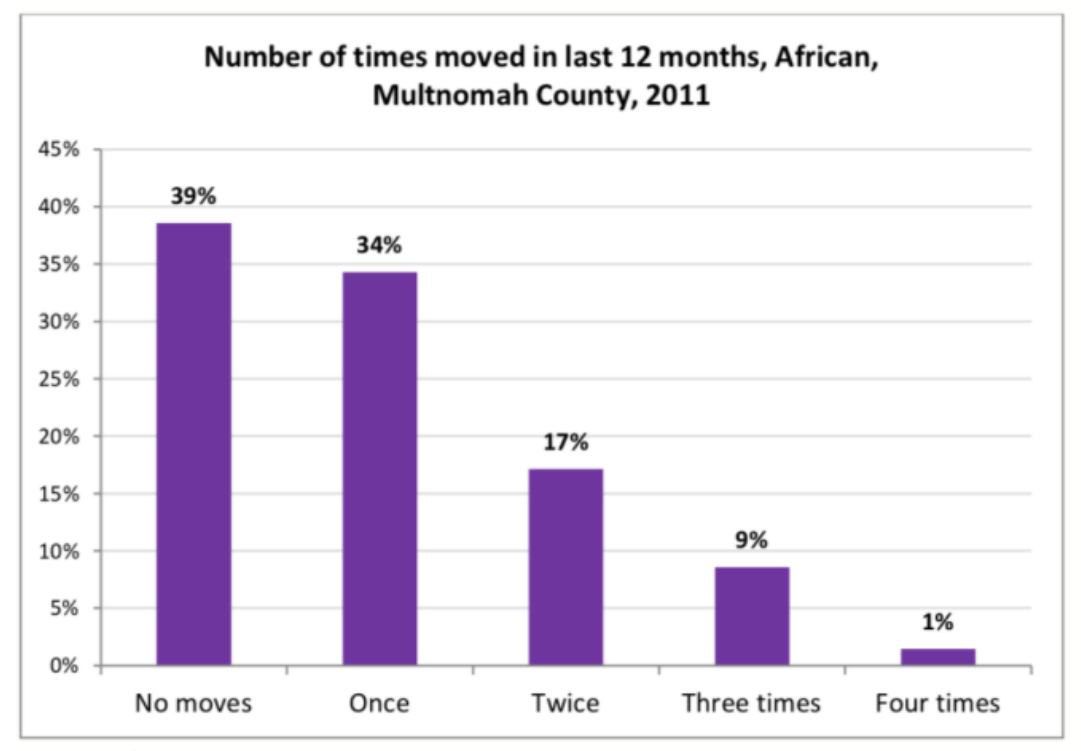

Figure 11. Number of Times that African Refugees and Immigrants Had to Move 2010-2011. It is shown that $51 \%$ is refugees had to move one or more times. Reproduced from Curry-Stevens, 2013. Data source African community survey, 2011 and American Community Survey, 2008.

\section{Vulnerability of Refugees}

In addition to the above cultural and financial barriers that refugees face, they are particularly vulnerable to housing stress given their lack of knowledge of their rights, language barriers, and cultural barriers. A cultural barrier that can cause tension and eviction for African immigrants is their difference of norms in occupancy, with some immigrants and refugees willing to live with many people in their apartment in order to make ends meet without understanding that this may break their lease terms. Advocating for the Somali community, Bashir, Muse \& Curry-Stevens emphasize that the lack of immigrant and refugees in stable housing situations is "not just a supply issue (2016, p. 11)." Muslim refugees face the barriers of some cultural beliefs not aligning with American systems that could support them, such as a prohibition of charging interest in Islamic faith that can keep some Muslim families from entering into traditional mortgages. 
Additional Barriers to Financial Success. It is important to note that refugees of color not only face the burdens of marginalization based on race within the primarily white city of Portland, but that they also encounter systemic barriers that inhibit them from easily accessing employment and other means of financial success. Refugees are required to accept the first job they are offered. This inhibits them from finding jobs that better suit their skills and needs, as they quickly become busy working in their new found jobs (Curry-Stevens, 2011, p. 33). In addition to this flaw in the system, there is a problem of a lack of recognition of foreign credentials in many cases, which results in many highly skilled immigrant workers working low wage jobs. Compounding these factors is the likelihood of discrimination, which is not legal but does occur towards people of color and immigrants. It is assumed this would translate into different industries where English and social skills are values. The amplifying effects of these factors are likely to be contributing to the dire economic situations that African immigrants and refugees faced following the recession when polled in 2011 (see Figure 12). 


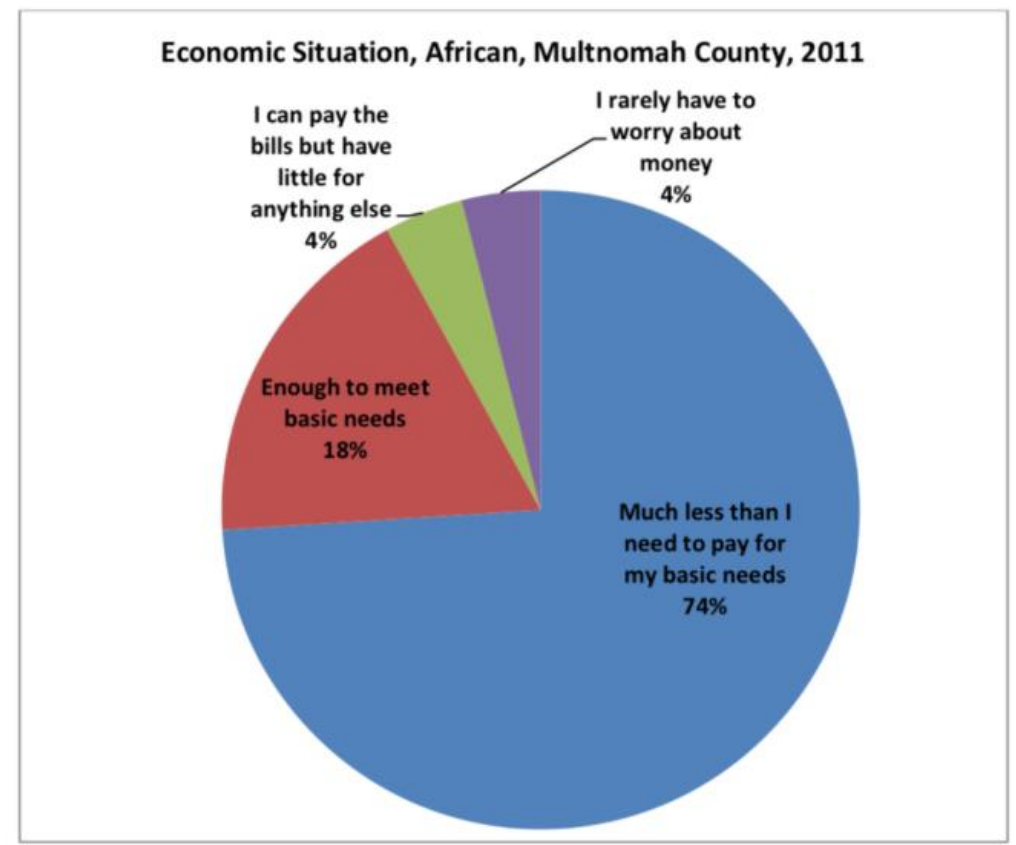

Figure 12. Economic Situations of African Immigrants and Refugees, Mult. Co., 2011.

Reproduced from Curry-Stevens \& Coalitions of Communities of Color, 2013 from the African Community Survey, 2011.

In order to address the barriers mentioned a list of recommendations specific for meeting the needs of African immigrants and refugees made by Curry-Stevens \& Coalition of Communities of Color recommended that African renters are given increased access to translators and that more policy is put in place that enables landlords and African renters to communicate through conflicts and disputes (2013).

\section{METHODS}

\section{Supportive Literature}

Previous studies have situated the experiences of various migrant and refugee groups in Portland. Some examine specific factors such as health care and the establishment of businesses have been in the region. The supporting literature that follows is not all specific to Portland, but some of it can arguably be used as a basis for beginning to identify some of the experiences that refugees in Portland may be having. Gaim Kibreab identified three factors that shape the 
experience of recently relocated refugees: attitudes of the receiving society, current policy environments, and employment opportunities in the communities they relocate to (Hume \& Hardwick, 2005). Kisson examined the role that poverty of asylum seekers can have in leading to homelessness (2010). Rose discusses the lack of attachment to a new place that migrants and forced migrants may feel (1995). She highlights that not identifying with a place is as important in understanding a sense of place as if one identifies with that place.

Looking at scholarly work that has been done regarding local communities, Hardwick and Hume looked at the ways that these factors influence the experiences of Sub-Saharan Africans, Russian migrants and Ukrainian migrants in Portland and the Vancouver Metropolitan Area, (2005). While Hardwick and Hume examined how immigrants and refugees have changed the landscape, this study looks at how the landscape has changed them.

\section{Positionality Statement}

As a white-passing Portlander, I know that I have the social capital and privilege that enables me to act in service to these communities. This thesis is an attempt to bring important issues to light that socially marginalized Portland communities are facing. My relationship with these groups is primarily beginning with this study, though my relationship with the places they mention include living in East Portland as a child. My grandmother is a first generation American and person of color, however, she moved here over fifty years ago in a different housing and political climate.

\section{Interview Process}

Five individuals were interviewed who worked at IRCO and one who worked at Catholic Charities. The original study design did not call for the participants to specifically work at IRCO, however, after recruitment, these were the respondents who replied to the opportunity to 
participate in the participation groups. The recruitment did not call for specific racial orientation or representation with the aim to put the least burden on IRCO and refugee communities while recruiting via an email memo and word of mouth. The original recruitment was oriented towards participants who were refugees themselves. After the interview began, it became known that some of the respondents were not refugees but all were within ethnic and cultural communities that had large numbers of refugees and worked with refugees routinely. After the interviews began, interviewees recruited their coworkers whom they felt were most familiar with these issues. The interviewees suggested some interview candidates with previously unrepresented diversity based on the final people interviewed, however, no one suggested connections to Slavic refugees. This was not realized until midway through recruitment, however, the initial aim to maintain the least amount of burden on the IRCO employees involved was respected rather than aiming to recruit specific races. Some of the interviewees were given pseudonyms to maintain their confidentiality, whereas two of them opted for the use of their given names.

One-on-one interviews were conducted at each person's place of work. The respondents helped to identify and recruit each other for the study. Each respondent was given a twenty-five dollar visa gift card and a local public transportation day pass (valued at five dollars).

Respondents who were unable to accept the gift personally due to work policies accepted the gift cards in order to redistribute them to clients of their organizations.

Identities of Interviewees. The five interview participants that worked for IRCO were all familiar with the struggles that refugees encounter due to their work and personal identities. Some of the interview participants have been given pseudonyms in place of their real names in order to protect their privacy. The respondents who have pseudonyms are indicated by the 
asterisk next to their name the first time it is mentioned. Two refugees, one asylee and two immigrants who were at IRCO were interviewed (see Table 5).

Table 5. Interviewee Information.

\begin{tabular}{|l|l|l|l|l|}
\hline Name & Place of Birth & $\begin{array}{l}\text { Immigration } \\
\text { Status }\end{array}$ & Years in the US & $\begin{array}{l}\text { Cities Lived in } \\
\text { U.S. }\end{array}$ \\
\hline Celia* & $\begin{array}{l}\text { Burma/ } \\
\text { Myanmar }\end{array}$ & Immigrant & Thirty-eight & $\begin{array}{l}\text { Portland, San } \\
\text { Francisco, Los } \\
\text { Angeles }\end{array}$ \\
\hline Djimet Dogo & Chad & Asylee & Seventeen & Portland \\
\hline Kanchha* & Bhutan & Refugee & Eight & Portland \\
\hline Quassayar Lami & Iraq & Refugee & Nine & Portland \\
\hline Omar* & Somalia & Immigrant & Two & Portland \\
\hline
\end{tabular}

Note: Self-created.

Quassayar Lami is one of the refugees interviewed. Moving here in 2008, he has worked at IRCO since a few months after his arrival as a job coach. One of the refugee respondents, Kanchha*, is a man from Bhutan who had been in Portland and the United States for eight years. One of the asylum respondents, Djimet Dogo, is a man from Chad who has been in Portland and the United States for seventeen years. Djimet has been interviewed in many publications across the city about issues that refugee communities face. Djimet is the Director of IRCO Africa House. One of the immigrant respondents, Celia*, is a woman from Burma (now Myanmar), who is part of a community of many Burmese refugees and has been living in the United States for thirty-eight years. She has lived both in Portland, San Francisco, and Los Angeles. The second immigrant respondent, Omar*, has lived in both Portland and the United States since 
2015. He is a male from Somalia. All of the interview participants had worked several positions in IRCO during their time involved with the center.

The respondents were not selected by their affiliation with IRCO or their country of origin, however, the resulting representation of some of the large cultural groups represented by refugees in Oregon and the United States acts as a point for analysis. No one was interviewed from an Eastern European country despite the large Eastern European population in Portland, noting that 'The Slavic Community in Multnomah County: An Unsettling Profile' covers some of the barriers and outcomes that Slavic communities experience (Curry-Stevens \& Coalition of Communities of Color, 2014). In 2002-2006, 2007, 2016 and 2017 the largest group of refugees that entered Oregon were from Ukraine. In 2010 the largest group of refugees admitted into Oregon were from Somalia. In 2016, 12,000 to 15,000 Somali people were recorded living in Oregon (Bashir, Muse \& Curry-Stevens, 2016). In 2011 and 2015 the largest group of refugees admitted into Oregon were from Burma. In 2008 and 2012 the largest group of refugees admitted was from Bhutan (Oregon Department of Human Services, 2018 ). In 2012-2014, the largest group of refugees admitted into Oregon were from Iraq (Office of Refugee Resettlement,2012; Office of Refugee Resettlement; 2013; Office of Refugee Resettlement, 2014). Djimet Dogo, the person interviewed from Chad, is not representative of a large refugee community in Oregon, with only five people from Chad living in the state (Djimet Dogo, personal communication, March 14 2018). However, Djimet Dogo is very involved in IRCO and has been working at IRCO for 19 years.

The questions asked included:

"How have the raising rents affected how comfortable you feel in Portland?"

"How long do you think you will live in Portland, Oregon?" 
"Based on your experience, what do you wish you could change about Portland?"

For a full list of the questions see Appendix B. The data was then analyzed and common themes were found and grouped into the overarching categories of negative versus positive perceptions or Portland.

\section{DATA: SENSE OF PLACE AND BELONGING IN PORTLAND, OREGON}

Geographic Distribution of Interviewees. Two of the five participants identified living in East Portland neighborhoods, including Lents, Mill Park, Russelville, Parkrose, and Centennial. Two of the immigrant respondents and one refugee respondent identified living in Northeast, as well as off of SW Barbur Blvd and in Beaverton. Two respondents said they were lucky to not have to rent from a stranger when they came to the area, instead living with community members and family. Respondents identified value in living near IRCO with some of them saying that they had moved farther out to seek larger homes to support their large families (of five or more people).Of those interviewed the majority of them had either rented from a landlord or community member at one point, with some of them currently owning homes.

Negative Refugee Perceptions and Experiences of Portland, Oregon. During the interview, each IRCO participant was asked about things that they do not like about Portland or things that do not make them feel "at home". Some of the identified negative themes that emerged include unaffordable housing, racism, and discrimination, and the location of cultural resources in proximity to affordable housing. One of the interviewees noted that placement agencies do not care whether an apartment is safe or clean.

Rising Rental Prices. All six people interviewed knew of refugees who struggled to pay their rent in Portland. Many of the interviewees spoke of how the result of this stress was refugees having to work two to five jobs to afford housing. Omar, the Somalian immigrant interviewed 
characterized this ongoing struggle when he said, "Our community are living day by day."

Qayssar Lami, an Iraqi refugee said that this stress causes refugees to focus on how to pay rent, saying that when he works with clients who cannot speak English and face additional barriers such as being single mothers, "We (IRCO) try(s) to find a way to have her survive and live comfortable in the U.S." A Somalian immigrant described some of the negative experiences he has had with the lack of affordable housing in Portland, stating that his family was ...coming to a point where we are thinking about how can we raise our kids here? We work only for rent. Imagine someone with skills, Bachelor degrees, and skills, who can speak five languages. If I'm complaining... what about our new arrivals with no English at all? No skills that are value(d) on the market? What about them? What about them? They are really suffering.

Concern for the disruption of children's education due to moving (both within and outside of Portland) was voiced by multiple respondents. Djimet Dogo, Chad asylee, said that IRCO clients "talked of many children having to go to three or four schools in one year due to their parents being forced to move often due to rising rental prices. The effects of these moves "It will disturb their education. Those are the consequences that we see in our community" (see Figure 13 for rates of child poverty in African refugee and immigrant communities). Family poverty rates for African immigrants and refugees in 2008 are shown. 


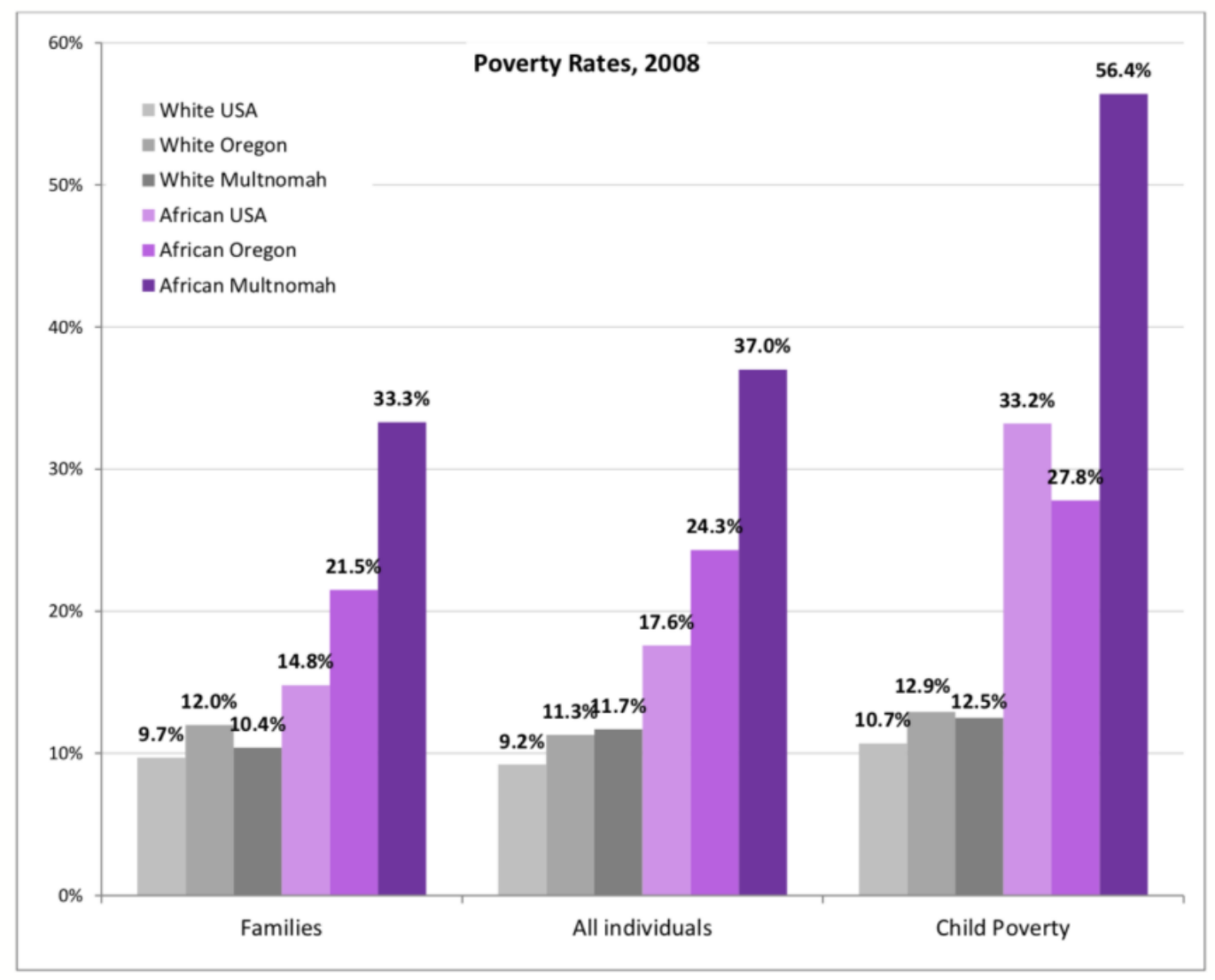

Figure 13. Poverty rates, 2008. Shown at the country, state and country scale. Reproduced from Curry-Stevens, 2013. Data from the Population Research center, Portland State University, the American Community Survey, 2008 for Multnomah county data, American Community Survey 2008.

An interesting phenomenon was described where refugees themselves contributed to gentrification and their own displacement from Rockwood apartments. Rockwood apartments, an apartment complex located in a suburb of Portland called Gresham (which borders East Portland), has frequently made the news over the years for a variety of reasons. As referenced earlier, the tension between refugees not making enough money to live in the greater Portland area and being displaced was brought to local media sources due to refugees leaving Rockwood. One of the interviewees described that refugees themselves contributed to the rising rental prices 
in the apartment complex by lowering the crime rate (which was previously reputable citywide). On IRCO's website, the organization advocates for hiring refugees as employees due to the reliability of their backgrounds, given the fact that in order to be admitted into the country, they have to go through extensive background checks and other security measures to determine that they are not a threat to their new communities (2018). This is a requirement that the United Nations mandates before allowing an asylee refugee status. In the case of the Rockwood apartments, the interviewee, Djimet Dogo, said because refugees were not involved in gang activity, they contributed to a reputation and reality of the apartment complex being a safer place to live. This attracted other low-income families, including Mexican immigrant families. Djimet explained that this led to a letter "out of nowhere" that raised the rent from 800 dollars to 1000 per month. The refugees were upset, saying that they fixed the place, and now they were being punished. Djimet said this was an example where it forces families to have one family member working two or more jobs, and the other no longer being able to stay at home to support the children. This theme of marginalized groups creating positive social change that is then co-opted and used to the advantage of business owners, landlords, and other groups, has also been expressed in recounts of gentrification in other neighborhoods and communities of Portland (Gibson, 2007).

All six respondents knew of refugees within their communities having to move outside of Portland due to rising rental prices. All of the locations that people were moving to were thought of as more affordable, and many were often in rural locations. Some refugees spoke of their community members moving to other states including Ohio, Idaho, Washington, Nebraska, Minnesota, North Carolina, South Carolina, Iowa, Alaska and Colorado. Other areas of Oregon that were discussed as relocation destinations include Salem and Eastern Oregon. The 
respondents voiced concerns over the potential hardships that refugees would (or are already) facing in rural areas, including the increased potential for racism, the lack of language resources, the lack of culturally specific foods available, the absence of other members of their community in the new locations (expressed as becoming "isolated") and how lack of cultural resources and language translators may negatively affect children's education.

Describing the hardships when a family moves from Portland to a rural area, Djimet Dogo told a story of a family moving to a rural town one hour out of Boise. He said they were one hour from Boise, living with no car and no public transportation. They did not have access to English as a Second Language (ESL) classes and there was no religious center. He spoke about the lack of culturally significant food in the area, saying that someone had to hire a taxi to take a family one hour into Boise in order to get ethnic food. He spoke of his concern for this family saying, "who's going to advocate for them? Who's going to orient them or give them directions?" He went on to say that people with medical conditions can be estranged from the specialists that they need to treat their conditions when they move to areas where there are no big hospitals.

A second health barrier was identified in the following story: Djimet Dogo spoke of a report in early 2018 that more than 150 refugees had moved to Ontario in Eastern Oregon. He said this was only the refugees on Temporary Assistance for Needy Families (TANF). He had heard apartments are available for 400-600 dollars in Ontario. Djimet spoke of how IRCO decided three years ago to move a refugee assistance representative to Salem, Oregon, but now housing prices have increased there, so more refugees are relocating to Independence and Corvallis. He was concerned about these moves "deep into rural areas that he felt were "far away from resources". One of his fears was that "nobody understand them" in their new rural 
locations. He then shared a story where lack of understanding was physically evidenced based on language barriers. In the story, a family struggled because medical transportation could not understand them. Djimet explained the result of this was that "A man pushed his wife three miles in a wheelchair to the clinic because he doesn't know how to call the clinic, and even if he did, he wouldn't know how to understand them."

Overall everyone interviewed felt that the current system could not support successful housing stability for the majority of refugees without changes (which will be discussed below). The current struggle that they faced was evident based on the sentiments of every person interviewed such as Qayssar Lami saying both "What should we do? We don't have a choice..." and that refugees needed higher wages in order to support themselves, "But, nobody listen to us... they just keep the way they are...".

Racism and Discrimination. Racism and discrimination were recurring negative themes in many of the interviews. One of the respondents, Celia*, from Burma/Myanmar, said "Oh, for you know what the thing that I don't like in Oregon not just Portland is I can feel that very racist... you know racist... but now I'm sort of kind of used to it." She felt that the racism and discrimination were becoming less obvious as Oregon became more diverse, however, other multiple respondents voiced a concern of increased discrimination and racism since the 2016 election. Djimet Dogo explained this tension by saying that "definitely the current administration in the past part of the history and Portland in particular since I've been here it didn't seem like, but now we see racism; we see discrimination" emphasizing that "especially since last summer('s) TriMet train (incident with a white supremacist attacking two young Muslim women) for us immigrant and refugee, we are so scared." He noted instances of children being bullied. Some of the programs that IRCO has offered in order to help provide safety or the 
feeling of safety for their immigrant and refugee communities are volunteer chaperones. These chaperones can escort immigrants and refugees to all kinds of necessary destinations from shopping for groceries to attending appointments.

\section{Positive Refugee Perceptions and Experiences of Portland, Oregon.}

Friendly, Progressive, Small and Safe. Despite complaints of discrimination and racism, all of the respondents generally viewed Portland as both friendly and "progressive". They also voiced that they favored the "political climate" that they saw as helping to support their acceptance into the community. Describing ways that Portland is small, progressive and friendly, Djimet Dogo, asylee from Chad said:

What I like about living in Portland instead of small we all know each other... (we have) serious community support. It is very progressive where people tend to help each other, (including) helping immigrants and refugees (by) making them feel welcome. It's easy to walk or bike. You don't have to worry about (how) accessible anywhere (is). Also Portland news(is) easy to talk to, (making it easier to talk to) decision-makers and officials.

Qayssar Lami, Iraqi refugee said safety is number one, contrasting the safety of Portland to the dangers that he has become familiar with in his home country. His definition of safety included lack of immediate threats such as car bombs and shootings happening often.

Natural Amenities. All respondents identified elements of nature as informing their sense of place in Portland. Both positivity and negativity were expressed regarding the rain in Portland. Specific geographical features that were identified include Mount Hood (which is visible from Portland, and reminded Kanchha of the beautiful landscapes in Kanchha home country of Bhutan), cherry blossom trees. Reaffirming the ways in which he has developed an attachment to Portland as a place, he said, "I fell in love with Oregon." Oregon was also described as "green" by Qayssar Lami. 
The Identified Importance of IRCO and other cultural services. Kanchha, a refugee from

Bhutan described the importance of IRCO as not only being service-related, but community and familiarity based. He expressed this when saying,

(IRCO has) more than 400 employees. More than 50 languages spoken within IRCO. It is like a small world for us... and people are diverse... they have different culture, different religion, but they live in harmony and trust. When you go to break room, you can smell food from Asia, from Africa, from every corner. We feel like families here.

One respondent said that without IRCO, he doesn't know how refugees would be surviving. Multiple respondents said that they feel IRCO is the main tool that refugees have to navigate "the system".

The interviewees identified four programs that help refugees (which were described earlier in this report), however, Kanchha was worried that IRCO hasn't... been supported to “develop a program where we can (help) clients who are severely unstable" citing instances where they could not help individuals who were disabled, who were homeless, regardless of if they had a family to support. Each program comes with specific guidelines and mandates that must be followed. The interviewee felt that this made it so there were many situations where people are "fully stuck" but were not qualified to get assistance from IRCO through their four primary programs.

The importance of other cultural services that may or may not be affiliated with IRCO was voiced when described the unique barriers a child refugee faced who went to David Douglas high school, in East Portland. The student was an orphan because both of their parents had been killed prior to their admission into the United States. The student knew little English but was placed at a grade level appropriate to their age level when they entered the high school. IRCO 
was able to recognize the ways in which the student, who has Post Traumatic Stress Disorder (PTSD) and had limited English skills, could use their services in adapting to their new lifestyle.

\section{The Role of Catholic Charities}

Catholic Charities does not directly sign leases for refugees, however, they help to provide translation and other communication support services between refugees and property owners when they sign their initial leases. The leases are generally one-year leases, even though refugees only receive financial assistance from the federal government for the first eight-months of their residency in the United States. Almost all of the interview respondents were familiar with or directly mentioned Catholic Charities, identifying them as an organization that had helped them when they first arrived in the country.

Catholic Charities offers some culturally specific services that help refugees with cultural adjustment. All refugees that receive Catholic Charities assistance are required to go through an orientation. Catholic Charities will offer culturally specific orientations if there is a high enough demand. One of the other services they offer is a language support group. One of their properties, Kateri Park, has a preschool and programs coordinator (Catholic Charities, 2017a). At one point the preschool had a large number of refugees, however, as the children age, the likelihood of the preschool remaining open looks slim. The types of programs that have been coordinated at Kateri Park include partnering with other organizations to provide fun and resourceful events for their residents (Catholic Charities, 2017b).

The housing units that Catholic Charities offers are subject to the same discrimination laws that other landlords and rental agencies must follow. This means that they do not prioritize or act as a pipeline for refugee housing applicants. Some buildings only rent to certain residents 
if they were funded under specific grants (such as senior housing units or units designated for people with disabilities).

The Catholic Charities employee interviewed identified refugee expectations being one of the hardest parts of their work. She explained that many refugees come to Portland with expectations of a different kind of life then they will have to live, with misconceptions about how much they will have to work and how inexpensive the city will be. The employee believes that all of the refugees that they work with are "housing insecure because they're income insecure". She said that due to the expensive housing market most refugees will have to wait for years before having the opportunity to live in designated low-income housing.

Another challenge that was identified by the Catholic Charities employee was the reality of the rising rental prices leading to a higher likelihood of refugees only being able to afford to live in low-quality homes, stating that Catholic Charities would never place refugees in an unsafe unit, but that they may only be able to afford unattractive units with limited amenities.

\section{DISCUSSION}

\section{Attachment to Place}

Despite the negative and positive experiences refugees had had in Portland, they all said they would stay as long as they could afford to and seemed to express that they had developed an attachment to place that is being negatively impacted (see Figure 14). 


\section{Gentrification leads to further individual and community displacement which leads to...}

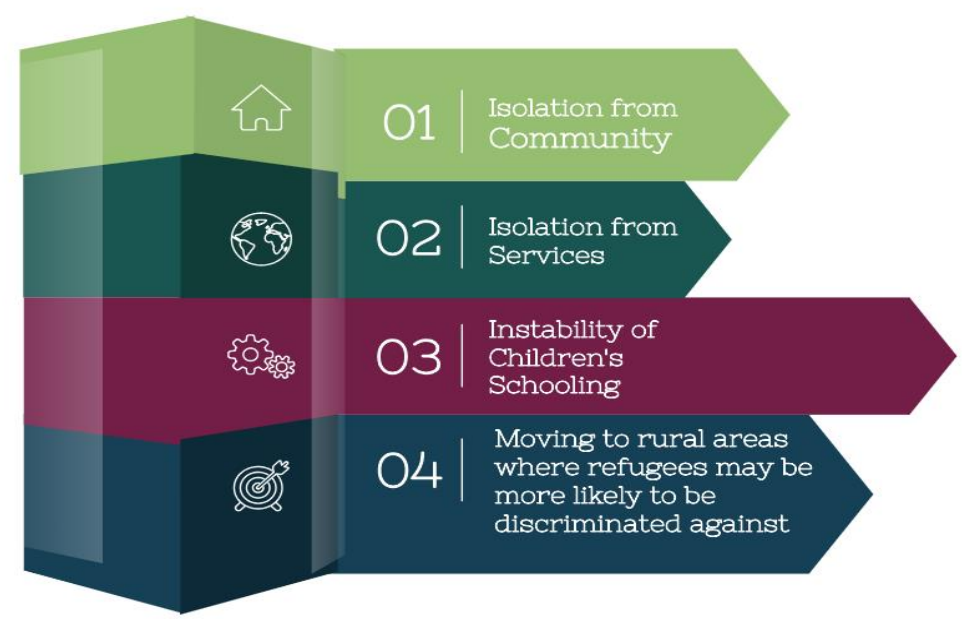

Figure 14. The Effects of Gentrification on Portland's Refugees. Self-constructed using the diagram featured by Slide Model, 2018.

Many gave specific stories, recounting when they or community members had to sacrifice the stability of their children's schooling by moving to a more affordable neighborhood. Refugees in Portland and across the United States have been documented as being more likely to have mental health issues (Bashir, Muse \& Curry-Stevens, 2016). The interviews conducted reinforce the relationship between financial stress and refugee health issues that is illustrated in the literature (Boise et al., 2013). As Living Cully explained, gentrification can lead to displacement and community displacement, which can lead to an array of negative feelings and reactions for those who have to move. How can Portland work to become a city where refugees are not faced with recurring displacements that negatively affect their perceptions of Portland and their health?

\section{Role of Community and Migration Networks}

A theme that was evident in every interview was the immense importance of having community and community members in the place that people decided to move to. Culture plays a 
large role in determining what the refugees considered their core community. It was found that some placement agencies do not consider the cultural clashes that may happen between people from different clans within the same country or different countries that have historical or current conflicts. This is also represented in the literature, as explained with the example of the Somali Bantus groups experience in Portland (Hardwick \& Meacham, 2014).

IRCO was shown to have an immense role in facilitating community and helping refugees to feel connected to place and at home. When interviewees were asked about the importance of IRCO they all emphasized the ways in which IRCO helps incoming immigrants and refugees both adapt to American culture and stay connected to their international cultures and communities. The critical importance of being connected to others in your community is illustrated by this quote from Kanchha a Bhutanese refugee, "When people die or when they are born we have our own community priest and if we do not find any priest here, I think it will be useless living here. We need our priest and if they are not here it is very hard for us."

Additional stressors that add to finding adequate housing for refugee families are the family sizes that differ across cultures. A story was told of a Congolese family of thirteen who were unable to find affordable housing together within Portland. The family took a van down to the state capital with the two parents and eleven children inside of their van, in order to appeal to legislators. They got lost along the way and ended up stopping at someone's private property in McMinnville, Oregon and tried to communicate that they needed directions. Despite the language barrier, the family whose farm they stopped at, eventually understood their needs and decided to take them in and start an advocacy campaign to address the issue. The link supporting this story in KOIN has now been taken down, though there is a post about the group in the 
politically charged conservative 'Refugee Resettlement Watch' website (Refugee Resettlement Group, 2014).

One of the interviewees told stories of instances where refugees have contributed to gentrification indirectly by making a neighborhood safer. Contrary to political debate and conservative media coverage, refugees who have committed serious crimes or have been identified as a threat to others would not be resettled in another country. Their non-involvement in the crime can create potentially safer neighborhoods.

The strong culture around community for refugee groups is another reason that one interviewee explained that it was harder for the public and city officials to see the number of refugees who may be homeless, but not living on the streets. He explained that refugees will stay illegally in each other's homes, offering support to community members rather than them having to live on the streets.

Migration networks helped to support refugees in finding areas where they heard of cheaper costs of living and shorter waiting times to get Section Eight or other affordable housing programs. Djimet talked of some refugees living in a place until their Section Eight voucher was allowed to be transferred, then moving back to Portland. He also spoke of families who had originally planned to do this, then changed their minds once they realized how much financially easier it was to live in the rural areas.

\section{Interviewees Suggestions for Addressing Rental Cost Problems}

As referenced earlier, there is growing concern among the refugee community and their supporting organizations (including Catholic Charities) about the reality of the federal assistance for refugees remaining at the same rate despite increasing living costs. Catholic Charities identified several structural barriers to the ways in which they are legally allowed to represent 
and support refugees. One of the barriers named is the way in which policy prevents Catholic Charities from applying for low-income housing before they arrive in the United States. Catholic Charities explained the ways in which low-income housing functions in a non-unified way across the city due to the different property owners that manage in different ways. This non-unified approach makes it so that Catholic Charities cannot quickly send one application that applies to all low housing options while waiting for available housing through the Section Eight voucher list. The Catholic Charities employee recognizes that when refugees come to the United States they "don't get a special pass", however, they receive both the rights and are expected to fulfill the responsibilities as other United States citizens while facing other barriers. Describing the wait for affordable housing in Portland, the Catholic Charities employee said that refugees “...get in line with everyone else. And that's a long line, and full of holes and it's broken" despite the additional barriers refugees may face including language literacy and knowledge of how to navigate the system.

The immigrants, refugees and asylees interviewed came up with a number of communitygenerated solutions that they had thought over and discussed over time. Multiple respondents called for rent control or to "stabilize rent" as a critical tool in alleviating the financial stress of rising rental prices. Other government-oriented solutions included increasing minimum wage. One of the interviewees felt that they should receive more support from the government that he pays taxes into. An additional unique solution proposed was to collect sales tax rather than high property tax to make home ownership more affordable. Several people interviewed expressed the idea of working closely with developers to designate more units reserved specifically for refugees, with an interviewee saying that this has already been done in Houston. IRCO has been sending representatives to Washington DC for two months in 2018 in order to advocate for the 
relocation of one of the refugee assistance organizations to address the movement of a large number of refugees from Salem to Ontario (Dogo, personal communication, March 14, 2018).

\section{Current Affordable Housing Initiatives in Portland}

Metro references that N/NE Neighborhood Housing Strategy, the Living Cully

EcoDistrict, and the Powell-Division Transit Action Plan are grassroots community grown initiatives that can serve as examples of local organizations advocating for public investment that address anti-displacement efforts (Metro, 2016). The N/NW Housing Strategy builds off of models used in New York, Massachusetts, California and through Home Forward by allowing local residents of those neighborhoods who are at risk of being displaced to be prioritized for the affordable housing that is constructed (Portland Housing Bureau, 2014). This model acknowledges the attachment to place that people grow in a neighborhood and how providing affordable housing away from historically used and developed resources do not address the needs of belonging and feeling at home.

Another important local initiative to examine is located in the East Portland area. The initiative reviewed is relevant to refugee communities because many of them live in the neighborhoods designated in this plan. The East Portland Neighborhood Office (EPNO) identifies members of these East Portland neighborhoods to be more likely than Portland residents in other neighborhoods to fall into the following categories:

- be a school-age child

- be a person of color

- be a non-English speaker

- pay higher property taxes compared to homes of similar value elsewhere

- live on an incomplete streets that are unsafe 
- not have a developed park within a reasonable distance from their home and be unable to locate a family-wage job near where they live (East Portland Neighborhood Office, 2016, p.1).

The East Portland Action Plan (EPAP) was developed by over 200 people in the course of one year. The EPAP outlines anti-displacement initiatives and tools for East Portland (East Portland Neighborhood Office, 2015). The plan both recognizes the importance of community involvement in anti-displacement measure and initiatives as well as the need to: "recognize that Municipal Governments have a responsibility to plan for the needs of and engage with disparately under-served, under-resourced, and under-represented communities, and to prioritize policy mandates based on need, so as to achieve greater equity for those most adversely impacted by gentrification/livability improvements “(East Portland Neighborhood Office, 2015, pg.1). Emphasizing the importance of equitable input into planning processes, the EPAP encourages governments to further empower communities in "meaningful participation ( East Portland Neighborhood Office, 2015, pg.2)". EPAP outlines sixteen actions that can be taken to alleviate the likelihood of displacement in East Portland. The actions outlined emphasize the need for giving infrastructural support for East Portland's residents, who have the highest percentage of "minorities" in Portland's population (East Portland Neighborhood Office, 2015,p.3). These actions can be found in Appendix C. The EPAP is available in seven languages online (East Portland Neighborhood Office, 2015). The Cooperative Ownership initiative may be a way for organizations and other entities to help fund adequate housing for refugees.

Cooperative Ownership functions through the practice of multiple families teaming together to purchase a property through the creation of a collective business corporation (East Portland Neighborhood Office, 2015, p. 10). 
EPAP's call for Inclusionary Zoning echoes many of the community generated solutions that interviewees shared. Inclusionary Zoning is explained in the EPAP report as follows:

This requires developers to make a percentage of housing units in a new residential development available to low and moderate-income households. In return developers receive non-monetary compensation in the form of density bonuses, zoning variances, expedited permits, or similar provisions that reduce construction costs or promote the developers goals. This can be done in developments with many single-family units or in multi-family developments (East Portland Neighborhood Office, 2015,p. 5).

Another neighborhood that has been identified as common for refugee and immigrant families to live is Cully, with Cully Association of Neighborhoods and Living Cully identifying the area as the most diverse neighborhood in the state (2016). 68 percent of Cully's residents spend more than 30 percent of their income on housing, compared to over $50 \%$ of Portland's renters in other neighborhoods (Living Cully, 2013, p. 25). Only 69 percent of Cully's residents speak English at home (compared to 81 percent for the rest of Portland) (Living Cully, 2013, p. 28). Despite Cully's identification as a high poverty neighborhood, Cully's neighborhood members are only receiving one percent more in public assistance than the citywide average. It is hypothesized that many of Cully's residents may into the categorization of the "working poor", where residents make incomes below the poverty level, but still do not qualify for public assistance (Living Cully, 2013, p. 29). Cully's residents are also more likely to live in a large family (with five or more people) than the citywide average (similar to the family structures of many refugee and immigrant interviewees) (Living Cully, 2013, p. 31).

Living Cully identified action items for mitigating against individual and community displacement. In aiming to "preserve housing affordability", their identified strategy is to "acquire and set aside land for affordable housing development" (Living Cully, 2013, p. 20). A 2013 study identified that most of the neighborhood was in early stages of gentrification (Bates, 2013). Living Cully sees an opportunity to prepare for changing the future of their 
neighborhoods. In 2011 the neighborhood had 25 affordable housing sites offering over 624 units of affordable housing (Living Cully, 2013, p. 21). One of the unique actions that they propose for future affordable housing development is to work with the county to "acquire tax delinquent properties that have reverted to county control (Living Cully, 2013, p. 20).” Living Cully also puts emphasis on education of tenant rights, with initiatives recommended including providing culturally specific outreach and hiring interpreters to work with immigrant and refugee communities. Similar to EPAP, Living Cully also emphasizes the importance of mitigating against commercial displacement (which may employee neighborhood locals or may help create an established sense of place) (2013).

Cully was in the media spotlight as an icon of the struggles that current renters are facing in 2017 when Normandy Apartment tenants received notice that their rent was going to raise over $100 \%$. The 18 tenant families who were unable to afford the change are all immigrants and refugees. Of the 18 tenant families, 26 elementary students attend Rigler Elementary School, making up more than five percent of the student body. Rigler is a Spanish Immersion and SUN school, and most of the affected residents were Hispanic or Latino (Monahan, 2017). Margot Black, of Portland Tenants United spoke on the damaging effect this change had been projected to have on the community, stating: "There is certainly nowhere they are all able to rehouse together, in the same community, not in the same building, not in the same block, not in the same neighborhood (Thomas, 2017)." The media coverage of this particular instance of the instability of housing in Portland's gentrifying neighborhoods was widely spread, which led to Multnomah paying $\$ 48,000$ in order to cover the difference in the rental raise for the children who would potentially be displaced (Barnes, 2017). A month after this public show of support, an estimated 300 people marched in the Cully neighborhood in support of the displaced children. Living Cully 
remained an active organizer throughout this public advocacy and support process, with a campaign of phone calls to the new landlords from the tenants and their supporters, as well as Living Cully's public support of a proposed bill to ban rent control (Solomon \& Flanigan, 2017). In April 2018, Cameron Herrington, an employee of Living Cully, and a Portland Housing Advisory Committee member gave an update of the situation at an event panel stating that only 8 of the 18 immigrant and refugee families were able to stay in the neighborhood (Institute for Sustainable Solutions). One of those eight families found the opportunity to live in an Accessory Dwelling Unit (ADU). Herrington stated that the ability to stay in the neighborhood depended on an "extraordinary confluence of circumstances" situating that the ability to find affordable housing in the same neighborhood should not be considered the norm. ADUs are currently being advocated for as a component of affordable housing solutions in Portland, with Commissioner Chloe Eudaly advocating for a permanent exemption from development fees for ADUs that are used for long-term rental (Monahan, 2018b). Commissioner Eudaly has shown her support for ADUs as a supportive measure with her push for a request for $\$ 2.1$ million dollars towards the development of ADUs, separate from the $\$ 410,000$ project that the city is undertaking in making four publicly financed ADUS for homeless Portlanders (Monahan, 2018a). Though the importance in the increase in government-financed support for Accessory Dwelling Units is acknowledged, it is also important to consider the other barriers that are not addressed with this financing, including changing a paradigm of what these small homes may represent in the minds of homeowners who may be resistant to their neighborhood changing with the influx of renters (Geffner, 2018). Another example is shown here where there is a tension between the sense of place of an established "insider" group, versus an incoming "outsider" group that would also like to make the said place their own. It is important to 
recognize both the already established refugee and immigrant families that are already there (as evidenced by the Normandy forced relocation example), and the distance Cully remains from key community resources such as IRCO. Though the work on increasing the number of accessible dwelling units is commended, ADUs do not address large family sizes, which the interview suggest are a need of various groups of refugees.

After gathering the citywide attention of residents and government alike, the extremes of Normandy were seen as fueling citywide discussions and commitments in the 2035 Comprehensive Plan. Worked on for four years, the critical input related to housing was from Anti Displacement PDX, a coalition of thirty local organizations that pushed for an 11 point antidisplacement and affordable housing plan to be included in Portland's 20-year plan. One of the policies that resulted in this plan specifically focuses on the impact that unstable housing can have on neighborhoods and schools and schooling (City of Portland, Oregon, 2016, GP5-9). The plan the city states they will fund at least 10,000 affordable housing units by 2035 (City of Portland, Oregon, 2016, p. GP5-10). The role that unaffordable housing can have in creating immigrant isolation is acknowledged, with a goal expressed to advocate developments that are in proximity to one another in recognition of the relationships that can foster (City of Portland, Oregon, 2016, GP5-13). The plan also hopes to address the identified gap between wage growth and housing costs. Within the 2035 plan, East Portland is acknowledged as a place where job growth is needed, as well as better support for minority-owned businesses.

Given that Portland does not have legal rent control, Portland City Council has oriented some of their housing emergency relief focus in the last few years on renter protections. One of the mandates that helps protect renters currently is Mandatory Renter Relocation Assistance. Additional efforts by the city include a $\$ 258.4$ million voting-backed bond passed in November 
2016 will fund the creation of 1,300 affordable homes for over 650 families. One of the properties purchased is in the Roseway-Cully northeast neighborhood, with the other major purchase in another northeast neighborhood (Portland Housing Bureau, 2018).

In the spring of 2016, further affordability housing incentives were supported through the passing of Senate Bill 1533 which is also referred to as the Inclusionary Zoning Code Project. This developer incentive based approach allows cities and counties to require affordable housing for up to twenty percent of units in multi-family structures through land use regulations and conditions (Bureau of Planning and Sustainability, 2016). The idea of inclusionary zoning speaks to the interviewee generated solution that certain units of affordable housing should be reserved specifically for refugees. One of the concerns with this proposal is the tension it creates between developers and the government, with inclusionary zoning itself not always being implemented successfully. In the case of Barnstable, MS developers brought an issue to court that could be an area of concern here: the claim by a developer that they are not able to make a profitable return on their property and feel that they are experiencing an "illegal tax" (Geffner, 2017 ).

Metro has published a draft framework for a regional general obligation bond measure centered on supporting affordable housing. It was set to be approved in late May to go on the 2018 ballot. The bond would provide housing for 6,300 to 10,000 people through a 50 dollar annual tax to Portland homeowners (p.2). Addressing some of the need expressed in the interviews is the mandate that half of the 3,2000 proposed homes would be 2 bedrooms or larger in order to accommodate families (Metro, p. 2, 2018). Other notable organizations that have been advocating for renter rights and education include the Community Alliance of Tenants and Portland Tenants United. 


\section{Racism and its Effects on Refugees' Experience of Portland}

"If other people of our origin are not here, we feel (we are) not safe to be." - Kanchha

Though this research does not focus on racism, it is important to note the relevance it has for refugees of color's lives. The refugees who were interviewed had two primary reasons for perceiving Portland negatively; the high cost of living as well as racism and fear of hate crimes (see Figure 15 for a hate crime outside of IRCO in 2014).

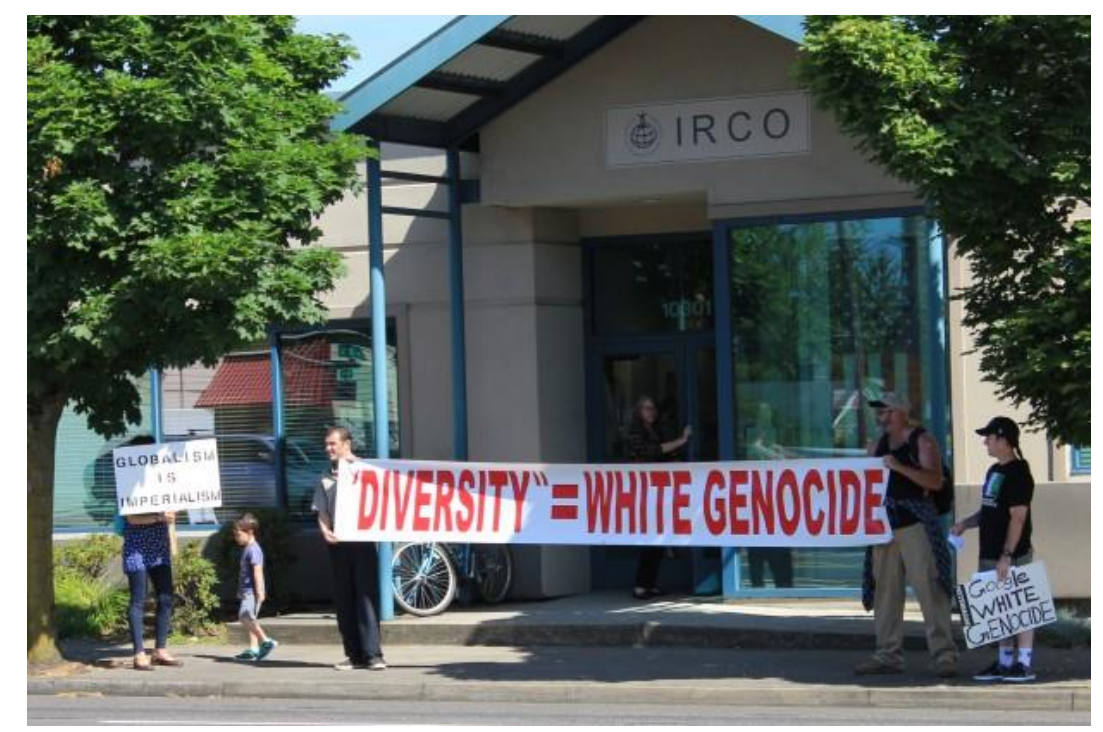

Figure 15. Anti-Immigration Rally, 2014. Reproduced from Silvis. Published on July 7th, 2014.

In the ten days following the election of United States president Donald Trump, the Southern Poverty Law Center cited 33 hate crimes occurring in Oregon (Johnson, 2018). This $200 \%$ increase in hate crimes has been theoretically linked to the President's anti-immigrant and refugee rhetoric, many of which specifically calls out members of populations that are a part of the refugee communities in Oregon (Johnson, 2018 ). In 2017, 104 hate crimes were reported (Federal Bureau of Investigation, 2017). The interviews conducted in this study revealed fear specifically related to the instance of hate crimes that occurred in Portland in 2017 and made the national news. One of the instances referenced was a violent attack by white supremacist Jeremy 
Christian that took the lives of two men and violently injured another while they were defending two teenage Muslim girls on public transportation (CBS News, 2017).

Though the connection between refugee racism and the housing market may not be explicit, it is important to consider the types of political climates refugees are being pressured into moving into due to rising rental prices. Many of the interviewees told stories of community members moving to rural areas, where some of them admitted more fear for a lack of belonging and understanding of the individual's diversity. The Southern Poverty Law Center has created a graphic that describes the motivations behind the spike in hate crimes that took place across the nation following the days of Trump's election (see Figure 16). This graphic illuminates the potential categories that refugees may be targeted for, including, but not limited to anti-black, anti-immigrant, anti-Muslim and white-nationalist ideals. It is shown that the largest number of hate crimes were categorized as anti-immigrant and anti-black.

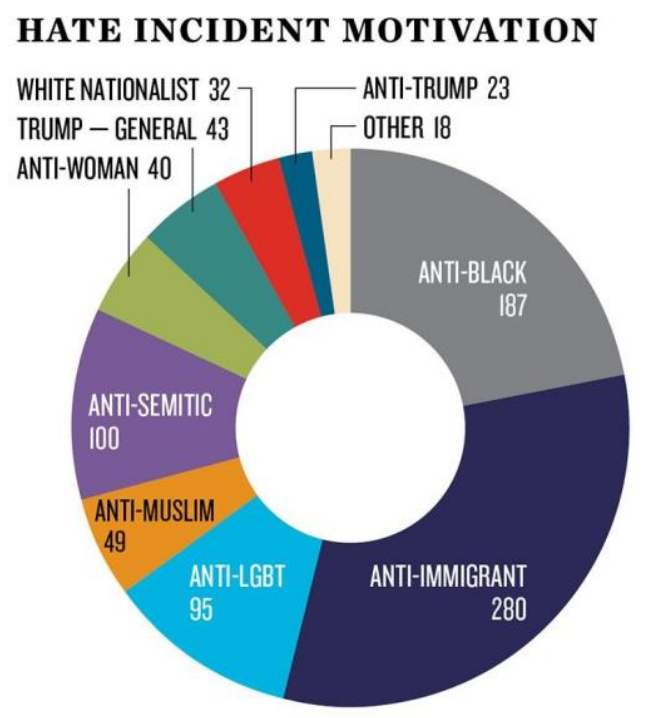

Figure 16. National Hate Crime Motivation. Graphic showing the motivations behind hate crimes that occurred nationally following the 2016 election. Reproduced from Johnson (2018). Recorded by the Southern Poverty Law Center. 
When refugees are displaced to rural areas within Oregon and Washington, much of the counties are "red" (or counties where the majority of the population is Republican). Though many Republicans do not support President Trump's anti-immigrant ideals, it still important to note that he was elected by Republicans into office and his campaign was openly full of this rhetoric.

The other areas that interviewees cited refugees being displaced to are primarily states that voted Republican in the election: Idaho, Ohio, North Carolina, Nebraska, Minnesota, Alaska (New York Times, 2017). A prolific hate crime against a Bhutanese owned grocery store made the national news in 2017 , with the hate crime scene including a note for immigrants and refugees to "go back where you came from" (Johnson, 2018). The democratic voting states that refugees were also cited as moving to are Colorado (mentioned once), Washington (mentioned once) and New York (mentioned once) (New York Times, 2017). This study does acknowledge the presence of hate crimes in democratic voting areas as well (see Figure 17).

AFRICA FOR THE AFRICANS, ASIA FOR THE ASIANS, WHITE COUNTRIES FOR EVERYBODY?

If "diversity" is so great, why does only one race have to practice it? If "diversity" is so great, why does it take a Police State to enforce it?

If "diversity" is so great, why is there White flight?

Anti-Whites say there should be no White Countries. Anti-Whites say there should be no White Towns. Anti-Whites say there should be no White Neighborhoods. Anti-Whites say there should be no White Schools. Anti-Whites say there should be no White Sports. Anti-Whites say there should be no White Anything.

Do anti-Whites really want a world without White people?

Is "anti-racist" a code word for anti-White?

Is "diversity" a code word for White Genocide?

Figure 17. Anti-Immigration Flyer. distributed in front of IRCO on July 7th, 2014. Reproduced from Silvis . 
Oregon has a history of white supremacist groups and crimes. One of the violent events that is still alive in the immigrant and refugee community's memory in Oregon was the 1988 murder of an Ethiopian immigrant by three white skinheads (Christensen, 1994). In 2016 Oregon was reported as the number one state where people were reporting instances of hate via ProPublica's Documenting Hate project. This data gathering project cites 44 instances of haterelated memorabilia, messages, and instances occurring in Oregon in 2016-2017. 18 of the instances were cited as "no more serious than graffiti", however, the type of graffiti can be seen as a form of violence in itself (see Figure 18) (Johnson, 2018).

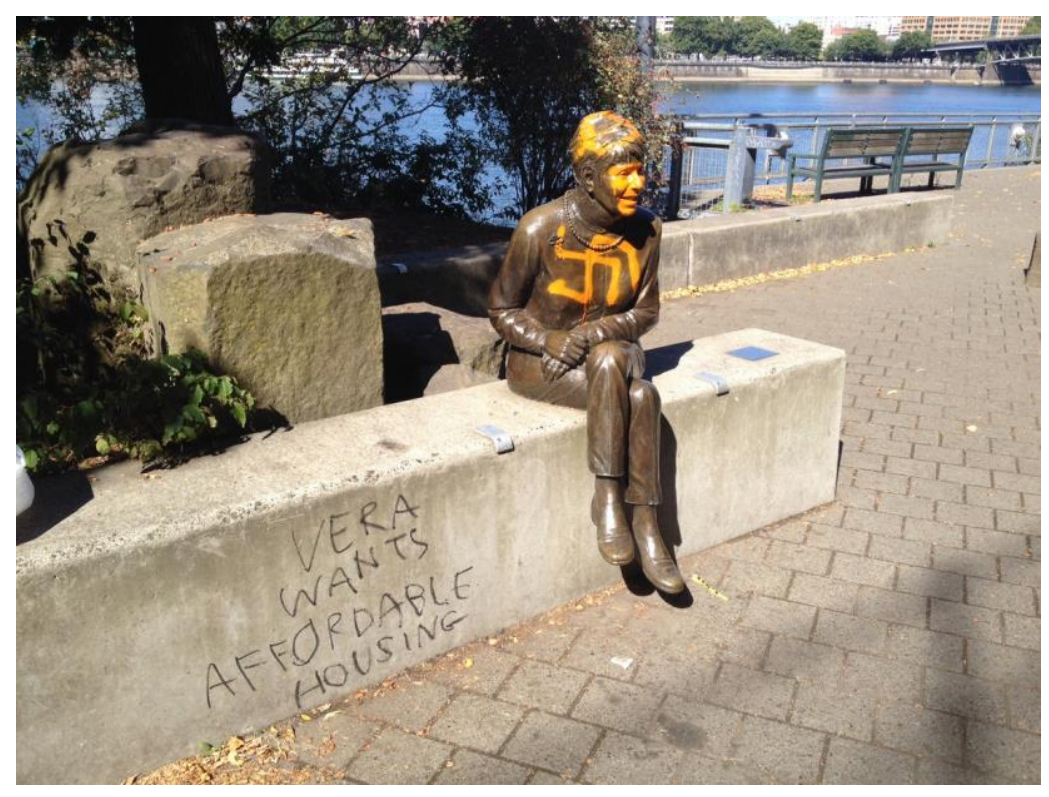

Figure 18. Anti-Semitic Graffiti (Vera Wants Affordable Housing). Shown on a statue of Former Portland Mayor Vera Katz, whose family fled Germany when the Nazi party rose ro power, and flew Europe during World War. Text reads "Vera wants affordable housing”. Photo taken on September 26th, 2016 by Andrew Theen. Reproduced from article by Tony Hernandez. Despite the fear of hate incited racist acts, interviewees also cited the ways in which they have been supported by communities Oregon and ways in which they feel accepted due to what multiple they described as a "political climate" that is "progressive" (anonymous, personal 
communication, 2018). Djimet Dogo, the interviewee who was an asylee from Chad, spoke of the struggle his community has faced as being members who are being on the 'banned list' under Trump's executive order. However, he said, "We have a lot of support from churches and Community organizations we hope within the next four years, it will go back to normal life." In 2016 Governor Kate Brown tweeted that "clearly" Oregon would continue accepting refugees, emphasizing the constitutional basis for accepting immigrants into the stat. She met with one of two Syrian families in Oregon (Parks, 2016).

Discrimination related to housing was found in Curry-Stevens and Coalition of Communities of Colors' African immigrant and refugee community health report. Evictions because landlords view having a large number of people in apartment as "crowding" (CurryStevens \& Coalition of Communities of Color, 2013,p. 87).

\section{Migration Networks}

One of themes that emerged from interviews with IRCO and Catholic Charities employees was the idea of migration networks. The Catholic Charities employee interviewed described refugees moving as "more of a pull than push," with a belief that people move because they are attracted to things in other places, rather than by rising rents. The other interviews seem to support theory that refugees who leave Portland often leave because of attractive attributes that they hear of in other places, including more affordable housing. Building off of the concept of migration networks, it is theorized that without word of mouth from community members in other places, it seems less likely that they would move to the new places that they decide to go to. During the interview with a Catholic Charities employee, an additional refugee destination was listed: Iowa (where some refugees were rumored to move because the section eight list was not as long). 
Economic displacement of refugees to rural areas not only distances them from cultural resources but also can lead to further distance between the refugees and their support programs. On December 1st, 2017 the Trump administration informed refugee support agencies that they would be closing all offices that were set to assist less than 100 refugees in 2018 . One of the states that will have one of its four refugee agencies shut down is Idaho- where many of the interviewed IRCO employees identified refugees relocating to. The Trump administration justifies the shutting down of these agencies as a sustainable and cost-reducing approach that advocates for a quick assimilation of refugees, both in the name of national security and selfsufficiency. Robert Carey, who directed the Office of Refugee Resettlement under the Obama administration, views this change as negatively affecting refugees' likelihood of cultural adjustment and economic contribution (Torbati \& Rosenberg, 2017). This will create situations where refugees who are moving to more rural areas have less access to valuable resources that help them to adapt to American life while they wait for the migration networks to develop. The importance of Portland as a hub for cultural resources is evident when it was stated that in 2013 "the only services" for African immigrants and communities were in Multnomah County (Curry Stevens \& Coalitions of Communities of Color).

\section{STUDY LIMITATIONS}

\section{Slavic Refugee Differentiation/Exclusion from Study}

With refugees from the former Soviet Union being the largest refugee group in Oregon (Kearns Moore, 2017), it is important to emphasize that this study is incomplete without their representation. Popular media interviews of Eastern European committee members find the variety of different issues they face, as a community that may generally externally appear to "fit in" to Portland's white majority despite their different cultural backgrounds, needs and diversity 
of viewpoints and experiences. The fair skin of Slavic refugees is seen as "invisibility" being "its own hardship", due to the lack of cultural and language specific communication and care that Slavic refugees may encounter when they go to seek services (Kearns Moore, 2017). There are different views within former Soviet Union refugee members about whether they agree with Trump policies, but many of them are seeing his election as an opportunity to mobilize and connect with other immigrant groups, including Somali immigrants (Kearns Moore, 2017). The Ukrainian community is also established geographically and culturally within certain parts of the city. More than 400 businesses were last reported as established (Hardwick and Meacham, 2005, p. 551).

\section{Further Limitations of the Study}

Other limits of this thesis small study include the small sample size and the individuals that were represented all know each other and work for some organization. Recommendations for continuing this work would involve finding greater ethnic and cultural representation throughout the study and involving more resource organizations including ethnic advocacy groups. In terms of study design, it is recommended to ask more questions about discriminatory practices that refugees have experienced with housing, with the idea for potentially using a focus group format for interview participants from the same ethnic groups. The work surrounding discrimination could expand in a number of ways, including looking at differences in treatment depending on gender affilitation.

\section{CONCLUSION: ACTION ITEMS TO ALLEVIATE REFUGEE STRESS}

In the context of Portland's rapid rate of gentrification of many neighborhoods, it is essential to consider how affordable housing can be further supported, particularly for populations who have documented additional economic and social vulnerabilities. In the current 
national political climate, Ben Carson, the Trump Administration's Secretary of Housing and Urban Development since 2017, has advocated for spending less money on affordable housing overall (The Washington Post, 2018). In combination with the increase in racist events (including hate crimes) nationally and locally, it is important to consider the unique barriers that refugees of color face in feeling that Portland is a comfortable place to live. With a history of discriminatory practices against people of color, particularly in the housing market, Portland is a unique place to examine these factors at play and how these stressors shape the experiences of incoming refugees of color. This study shows the ways in which refugees in Oregon may be beginning to develop senses of place that support feelings of attachment and belonging that are threatened by the instability of accessibility to affordable housing that gentrification causes.

The recommendations generated from the interviews include policy oriented measures (see Figure 19). All of the interview generated solutions should be investigated further, taking into account their practical applications in the local economic and governmental systems. Interview generation solutions 1, 3 and 4 (see Figure 19) are not refugee specific. The recommendation from this study should be implemented at the federal level is the increase in federal stipend time or amount dependent on local economies. If this recommendation is not feasible (which it seems unlikely to be implemented under the current administration) affordable housing measures should be invested in with efforts to determine how refugees can be given increased opportunities for accessing the limited affordable housing supply in Portland. 


\section{Interview Generated Solutions}

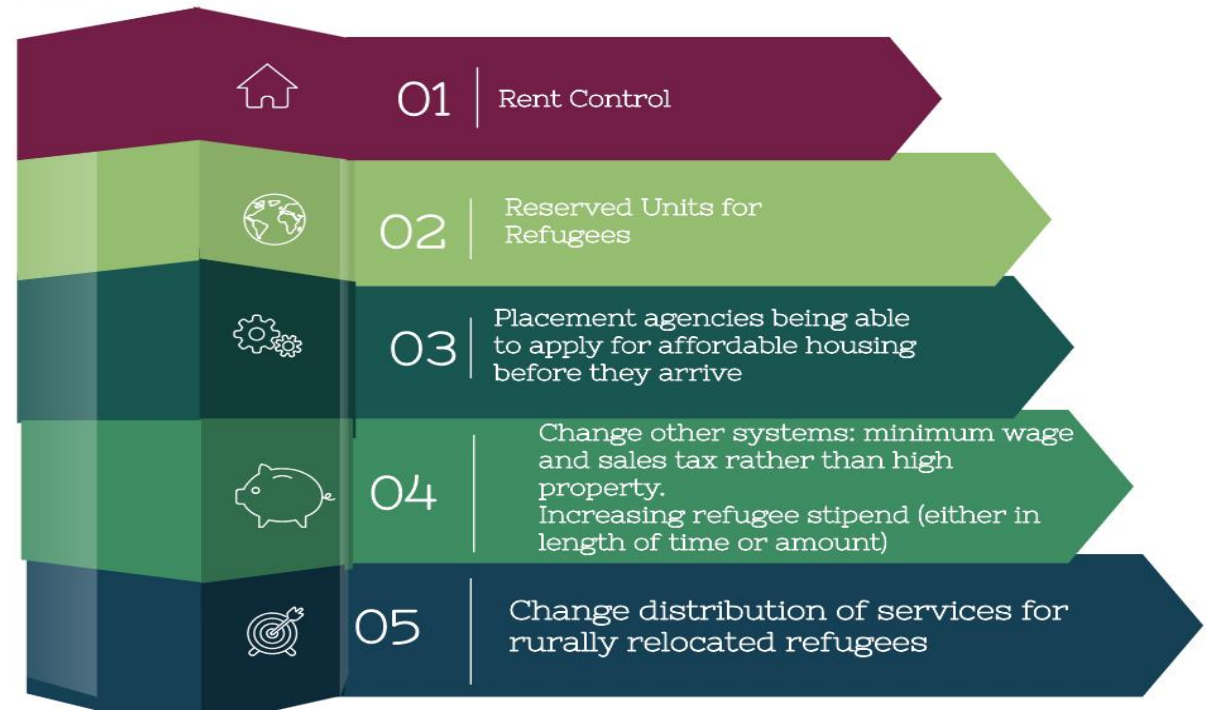

Figure 19. Portland Refugee Community Member's Interview Generated Solutions. 2018. Selfconstructed using the diagram featured by Slide Model, 2018.

In addition to policy measures, it is important to note the role that people living in Portland can help to address gentrification and racism. Portlanders should think about the role they can have in creating a more welcoming community, as well as actively advocating for refugee rights through ally-ship. The examples given show how community based non-profits and neighborhood organizations have been important venues for marginalized communities to have their voices heard and have platforms for organization. The ways in which these platforms can contribute to social change was evidenced by Living Cully's participation in AntiDisplacement PDX, the organization that advocated for an eleven point anti-displacement and gentrification proactive policy plan that was included in the 2035 citywide plan. Those with the social capital to do so should consider the roles they can have as potential allies for refugees, noting that they may be at less risk for retaliation and discrimination when they voice their opinions. Groups that have the resources should also invest time and money into elevating the voices of those who do not have social capital within Portland. These organizations should 
recognize that marginalized communities, including refugees of color, often have some of the least amount of time to spare due to the likelihood that they may be dedicating the majority of their time to either working multiple jobs or commuting long distances to the employment that is available to them. Recognizing this, organizations and researchers from institutions must attempt to secure funding to provide for those voices that they are asking to be heard. Though Portland is considered a "Sanctuary City" and many major institutions in Portland (including Portland State University) have shown support for this initiative, the city still has very much work to do in terms of addressing historical policies of racism and discrimination that have displaced communities of color and created environments where white voices are the often the most represented and heard in these issues (Wiewel, 2017). An overarching determinant on all of the identified social issues that the "solutions" proposed is how the government of a region treats housing, and whether it is considered as part of the definition of human rights. Curry-Stevens and Coalition of Communities of Color insist that "it is important that housing be understood as a human right instead of a consumption item..." (2013 p. 10).

This study aimed to provide further scholarly support by including an important conversation about refugee experiences in the literature, in the hopes of establishing a basis for further study and action that will support the quality of life of refugees in Portland. The aim of creating bodies of scholarly work within this discourse is to assist refugees' positive perceptions and senses of place in Portland through illuminating and advocating for the factors that help them feel connected to, and comfortable in Portland. The current study emphasizes the ways in which refugees must be able to access housing stability in order to obtain better qualities of life that allow them to have the capacity to continue to contribute to the ways in which cities are sustained both socially and economically. 


\section{WORKS CITED}

Anonymous, personal communication, February 28, 2018.

Barnes, B. (2017, February 02). County to pay rent for 26 Portland children so they don't have to change schools. Retrieved from http://www.oregonlive.com/education/index.ssf/2017/02/county_to_pay_rent_for_26_por t.html

Bashir, A., Muse, A., \& Curry-Stevens, A. (2016, August 24). Oregon Somali Community Needs Assessment. Retrieved from https://multco.us/file/56387/download

Bates, L. K. (2013). Gentrification and Displacement Study: implementing an equitable inclusive development strategy in the context of gentrification (pp. 1-95, Rep.). Portland, Oregon: City of Portland Bureau of Planning and Sustainability.

Boise, L., Tuepker, A., Gipson, T., Vigmenon, Y., Soule, I., \& Onadeko, S. (2013). African Refugee and Immigrant Health Needs: Report From a Community-Based House Meeting Project. Progress in Community Health Partnerships: Research, Education, and Action, 7(4), 359-360. doi:10.1353/cpr.2013.0054

Brar-Josan, N. (2015). Developing A Sense of Belonging During Resettlement Amongst Former Refugee Young Adults. (Dissertation, University of Alberta, 2015), II-146. Retrieved May 7, 2018

Bureau of Planning and Sustainability. (2016). Inclusionary Housing Zoning Project As-Adopted Report (pp. 1-125, Rep. No. 188162). Portland, OR: City of Portland.

Catholic Charities. (2017a). Home | Kateri Park Preschool Portland Oregon. Retrieved December 05, 2017, from https://www.katerikids.org/

Catholic Charities Oregon. (2017b). Ways To Give. Retrieved December 05, 2017, from https://www.catholiccharitiesoregon.org/provide-shelter/resident-services/

CBS News. (2017, May 31). Portland stabbing survivor says city has "white savior complex". Retrieved from https://www.cbsnews.com/news/micah-fletcher-portland-stabbingsurvivor-says-city-has-white-savior-complex/ 
CBS News. (2017, May 27). Suspect named in killing of 2 people who defended Muslim women. Retrieved from https://www.cbsnews.com/news/jeremy-joseph-christianportland-stabbing-Muslim-hate-speech/

Christensen, L. W. (1994). Skinhead Street Gangs. Boulder, CO: Paladin Press.

City of Portland, Oregon. (2016). 2035 Comprehensive Plan: Goals and Policies. Retrieved from https://www.portlandoregon.gov/bps/70937

Coalition of Communities of Color. (2018). Members. Retrieved from http://www.coalitioncommunitiescolor.org/ccc-members/

Cresswell, T. (1996). In placelout of place: Geography, ideology, and transgression. Minneapolis: University of Minnesota Press.

Cresswell, T. (2015). Place: An introduction (2nd ed.). Chichester, West Sussex: Wiley Blackwell.

Cully Association of Neighbors, \& Living Cully. (2016). Cully Air Quality Letter [Letter to Governor Kate Brown]. Cully, Portland, Oregon.

Curry-Stevens, A. \& Coalition of Communities of Color (2013). The African Immigrant and Refugee Community in Multnomah County: An Unsettling Profile. Portland, OR: Portland State University.

Curry-Stevens, A. \& Coalition of Communities of Color (2014). The Slavic Community in Multnomah County: An Unsettling Profile. Portland, OR: Portland State University.

Curry-Stevens, A., Hemmer, A., \& Coalition of Communities of Color. (2010). Communities of Color in Multnomah County: An Unsettling Profile. PDXScholar, 1-150. Retrieved May $18,2018$.

Dogo, D, personal communication, March 14, 2018

D.L. Mayfield | Published September 13, 2016 Updated September 20. (2016, September 13). I Moved to the Edge of Portland to Help Refugees. But They Can't Afford to Live Here Anymore.

East Portland Neighborhood Office. (2015). East Portland Action Plan City Candidate Questionnaire - May 2016 Primary Election [Brochure]. Portland, OR: Author. 
http://eastportlandactionplan.org/sites/default/files/Revised 2016.04.29 East Portland Action Plan 2016 City Candidate Questionnaire with Responses_0.pdf

Federal Bureau of Investigation. (2017, October 25). Hate Crime Statistics 2016. Retrieved from https://ucr.fbi.gov/hate-crime/2016

Flanigan, P. (2017, February 26). Oregon Has A Complicated History With Rent Control. Retrieved from https://www.opb.org/news/article/oregon-portland-rent-control-banhousing-history/

Floum, J. (2017, October 04). Portland 'housing emergency' and renter protections up for extension at Portland City Council. Retrieved from http://www.oregonlive.com/politics/index.ssf/2017/10/portland_housing_emergency_and .html

Geffner, T. (2017, August 3). Land Use Zoning in America: A Case for Inclusionary Policy. Anthos.

Geffner, T. (2018, March 2). Towards a Smaller Housing Paradigm: A Literature Review of Accessory Dwelling Units and Micro Studios. PDXScholar. Retrieved from https://pdxscholar.library.pdx.edu/cgi/viewcontent.cgi?article $=1636 \&$ context=honorsthes $\underline{\text { es }}$

Gibson, K. J. (2007). Bleeding Albina: A History of Community Disinvestment, 1940-2000. Transforming Anthropology, 15(1), 3-25. doi:10.1525/tran.2007.15.1.03

Gomez, A. (2018, January 03). Refugee admissions to U.S. plummet in 2017. Retrieved from https://www.usatoday.com/story/news/world/2018/01/03/refugee-admissions-u-splummet-2017/999903001/

Greenstone, S. (2016, June 6). Oregon's Soviet Diaspora: 25 Years Later, The Refugee Community Wants To Be Known. Retrieved from https://www.opb.org/radio/programs/thinkoutloud/segment/oregon-soviet-diasporarefugee-community/

Gregory, D., Johnston, R., Pratt, G., Watts, M., \& Whatmore, S. (Eds.). (2009). The dictionary of human geography (5th ed.). Chichester: Wiley-Blackwell.

Haider-Markel, D. P., Card, M. A., Gaddie, R. K., Moncrief, G., \& Palmer, K. T. (2009). Political encyclopedia of U.S. states and regions. Washington, D.C.: CQ Press. 
Hardwick, S. W. (2009, November 23). Far from Home. Retrieved from https://oregonhumanities.org/rll/magazine/away-fall-winter-2009/far-from-home/

Hardwick, S. W., \& Meacham, J. E. (2005). Heterolocalism, Networks of Ethnicity, and Refugee Communities in the Pacific Northwest: The Portland Story. The Professional Geographer, 57(4), 539-557. doi:10.1111/j.1467-9272.2005.00498.x

Hardwick, S.W, \& Meacham, J.E (2014). 'Placing' the Refugee Diaspora to Portland, Oregon: Suburban Expansion and Densification in a Re-Emerging Gateway. Book, 1-35. Retrieved November 1, 2017.

Hernandez, T. (2016, September 21). Vera Katz statue vandalized with Nazi swastika. Retrieved from http://www.oregonlive.com/portland/index.ssf/2016/09/vera_katz_statue_vandalized_wi. html

Hume, S. E., \& Hardwick, S. W. (2005. African, Russian, And Ukrainian Refugee Resettlement In Portland, Oregon. Geographical Review, 95(2), 189-209. doi:10.1111/j.19310846.2005.tb00362.x

Immigrant Refugee Community Organization. (2016). 2016 Annual Report (pp. 1-15, Rep.). Portland, OR: IRCO.

Immigrant Refugee Community Organization. (2017). 2017 Annual Report (pp. 1-16, Rep.). Portland, OR: IRCO.

Immigrant \& Refugee Community Organization - Who We Are. (2018). Retrieved from https://irco.org/who-we-are/

Institute for Sustainable Solutions, Portland State University. (2018, April 26). Accessory Dwelling Units: Can ADUs provide affordable, equitable, and sustainable housing. Lecture presented at Accessory dwelling units: Opportunities and limitations in Oregon, Portland.

Johnson, D. (2018, March 1). Report: Rise in hate violence tied to 2016 presidential election. Retrieved from https://www.splcenter.org/hatewatch/2018/03/01/report-rise-hateviolence-tied-2016-presidential-election 
Kearns Moore, S. (2017, January 31). Former Soviets - the largest refugee group in Portland also divided by Trump issues. Retrieved from https://portlandtribune.com/pt/9news/342574-222214-former-soviets-the-largest-refugee-group-in-portland-also-dividedby-trump-issues

Keller, J. (2011) Experiences of Public Housing Residents Following Relocation: Explorations of Ambiguous Loss, Resiliency, and Cross-Generational Perspectives, Journal of Poverty, 15:2, 141-163, DOI: 10.1080/10875549.2011.563170

Kissoon, P. (2010). From Persecution to Destitution: A Snapshot of Asylum Seekers' Housing and Settlement Experiences in Canada and the United Kingdom. Journal of Immigrant \& Refugee Studies, 8(1), 4-31. Retrieved May 7, 2018.

Kubein, A. M. (2015). Portlandia's Other Children: Refugee Communities in Urban Life (Dissertation, Oregon State University, 2016) (p. 0-255). Corvallis.

Lami, Q. Personal Communication, May 14, 2018.

Lind, D. (2017, October 03). The Trump administration doesn't believe in the global refugee crisis. Retrieved from https://www.vox.com/policy-andpolitics/2017/10/3/16379016/trump-refugees

Living Cully: A Portland EcoDistrict. (2013). Not In Cully: Anti-Displacement Strategies for the Cully Neighborhood (pp. 1-46, Publication). Portland, OR: Living Cully.

Maslow, A. H. (1987). Motivation and personality (3rd ed.; R. Frager, J. Fadiman, C. McReynolds, \& R. Cox, Eds.). New York, New York: Longman.

Massey, D. B. (1994). Space, place, and gender. Minneapolis (Minnesota, Estados Unidos): University of Minnesota Press.

Mayfield, D.L. | Published September 13, 2016 Updated September 20. (2016, September 13). I Moved to the Edge of Portland to Help Refugees. But They Can't Afford to Live Here Anymore.

Mesh, A. (2015, September 29). Portland's Rent Spike Spreads East, Pressuring Low-Income Residents. Willamette Weekly. Retrieved November 27, 2017, from http://www.wweek.com/news/2015/09/30/portlands-rent-spike-spreads-east-pressuringlow-income-residents/ 
Metro. (2016). Opportunities and challenges for equitable housing (pp. 1-50, Publication). Portland, OR.

Metro. (2018). Homes for greater Portland Regional housing measure: Draft framework [Pamphlet]. Portland, OR.

Monahan, R. (2016, January 24). A 100 Percent Rent Hike at a Northeast Portland Apartment Building Could Force 26 Rigler Elementary School Students to Move. Retrieved from http://www.wweek.com/news/city/2017/01/24/a-100-percent-rent-hike-at-northeastportland-apartment-building-could-force-40-rigler-elementary-school-students-to-move/

Monahan, R. (2018a, March 14). Portland's Backyard Cottages Will Get a Permanent Exemption From Development Fees-With One Restriction. Retrieved from http://www.wweek.com/news/city/2018/03/14/porlands-backyard-cottages-will-get-apermanent-exemption-from-development-fees-with-one-restriction/

Monahan, R. (2018b, February 7). Portland City Commissioner Chloe Eudaly Seeks to Spark Increase in Backyard Cottages and Other ADUs. Retrieved from http://www.wweek.com/news/city/2018/02/07/portland-city-commissioner-chloe-eudalyseeks-to-spark-increase-in-backyard-cottages-and-other-adus/

Monahan, R. (2016, August 19). What's the Deal with Portland's Rising Rents? Willamette Week. Retrieved November 27, 2017, from http://www.wweek.com/news/2016/08/19/the-state-of-portland-rental-breakdown/

Mott, Tamar. (2010) African refugee resettlement in the US: the role and significance of voluntary agencies, Journal of Cultural Geography, 27(1), 1-31, DOI: $10.1080 / 08873631003593190$

Office of Refugee Resettlement. (2009). Annual Report to Congress 2009 (pp. 1-181) (Office of Refugee Resettlement, Administration for Children and Families). United States Department of Health and Human Services.

Office of Refugee Resettlement. (2015). Annual Report to Congress: Fiscal Year 2015 (pp. 166). (Office of Refugee Resettlement, Administration for Children and Families). United States Department of Health and Human Services.

Office of Refugee Resettlement. (2012). Fiscal Year 2014 Refugee Arrivals (USA, Office of Refugee Resettlement, Administration for Children and Families). United States Department of Health and Human Services. 
Office of Refugee Resettlement. (2013). Fiscal Year 2014 Refugee Arrivals (USA, Office of Refugee Resettlement, Administration for Children and Families). United States Department of Health and Human Services.

Office of Refugee Resettlement. (2014). Fiscal Year 2014 Refugee Arrivals (USA, Office of Refugee Resettlement, Administration for Children and Families). United States Department of Health and Human Services.

Oregon. ORS 91.225. 2017

Oregon Department of Human Services. (2016). Refugees in Oregon Data. Retrieved from http://www.oregon.gov/DHS/ASSISTANCE/REFUGEE/Pages/data.aspx

Oregon Department of Human Services. (2018). Refugee. Retrieved from http://www.oregon.gov/DHS/ASSISTANCE/REFUGEE/Pages/data.aspx

Oregon Office of Economic Analysis. (2017, February 16). Foreign-Born Oregon Residents. Retrieved from https://oregoneconomicanalysis.com/2017/02/16/foreign-born-oregonresidents/

Pan, Y. (2017, January 23). The U.S. Cities That Are Gentrifying the Fastest-You'll Never Guess No. 1. Retrieved from https://www.realtor.com/news/trends/10-surprising-cities-that-aregentrifying-the-fastest/

Parks, C. (2016, February 04). Oregon's first Syrian refugee family meets with Kate Brown. Retrieved from http://www.oregonlive.com/portland/index.ssf/2016/02/oregons_first_syrian_refugee_f.ht $\underline{\mathrm{ml}}$

Perry, D. (2017, July 05). 'Go back to California!' graffiti on car, house stuns new arrivals, highlights old tensions in Portland. Retrieved from http://www.oregonlive.com/portland/index.ssf/2017/07/go_back to_california_vandalis.h tml

Portland Housing Bureau. (2014). North/Northeast Neighborhood Housing Strategy Executive Summary (pp. 1-9) (United States of America, City of Portland, Oregon, Portland Housing Bureau). Portland, OR.

Portland Housing Bureau. (2018, February 28). Purchase and Sale Agreement to Acquire Property in Roseway-Cully. Retrieved from 
https://portlandhousingbond.com/news/2018/2/28/purchase-and-sale-agreement-toacquire-property-in-roseway-cully

Portland, Oregon. Ordinance 188627. September 26th, 2017.

Refugee Resettlement Group. (2014, September 08). Oregon: Congolese refugee family of 13 was homeless all summer. Retrieved from https://refugeeresettlementwatch.wordpress.com/2014/09/08/oregon-congolese-refugeefamily-of-13-was-homeless-all-summer/

Rose, G. (1995). Place and Identity: A Sense of Place. In D. Massey \& P. Jess (Authors), A Place in the World? (pp. 88-118). Oxford: Oxford University Press.

Semuels, A. (2016, July 22). The Racist History of Portland, the Whitest City in America. Retrieved from https://www.theatlantic.com/business/archive/2016/07/racist-historyportland/492035/

Silvis, H. (2014, July 7). Outside IRCO Protesters Claim Diversity Equals Anti-White ... Retrieved from http://www.bing.com/cr?IG=B2929A92BF7045DB88CE69C52D85C266\&CID=258950 211253696F1B115BD013FC68B0\&rd=1\&h=gwDDEadBuVMuKS79seS5QfDW_gFvWkliSWRlmC4IaI\&v=1\&r=http://www.theskanner.com/news/northwest/21485outside-irco-offices-protesters-claim-diversity-equals-anti-whitegenocide \&p=DevEx.LB.1,5555.1

Slide Model, 2018. Slidemodel.com

Solomon, M., \& Flanigan, P. (2015, February 25). Hundreds March In Northeast Portland Rally To Protest Rent Hikes. Retrieved from https://www.opb.org/news/article/portland-rent-i increase-rally-normandy/

Sparling, Z. (2017, August 29). Refugee Numbers Plummet. Retrieved from https://pamplinmedia.com/go/42-news/370463-252707-refugee-numbers-plummet

Steele, T. (2015, December 15). Priced out neighbors 'may have to move to survive'. Retrieved from http://www.koin.com/archives/i-may-have-to-move-just-to-survive/960232308

The New York Times. (2017, August 9). Presidential Election Results: Donald J. Trump Wins. Retrieved from https://www.nytimes.com/elections/results/president 
The Washington Post. (2018, April 25). Ben Carson proposes raising rent for low-income Americans receiving federal housing subsidies. Retrieved from http://www.oregonlive.com/today/index.ssf/2018/04/ben_carson_proposes_raising_re.ht $\underline{\mathrm{ml}}$

Thomas, K. (2017, January 25). Tenants at NE Portland apartment complex face 100 percent rent hike. Retrieved from http://katu.com/news/local/tenants-at-ne-portland-apartmentcomplex-face-100-percent-rent-hike

Torbati, Y., \& Rosenberg, M. (2017, December 22). Exclusive: State Department tells refugee agencies to downsize U.S... Retrieved from https://www.reuters.com/article/us-usaimmigration-refugees-exclusive/exclusive-state-department-tells-refugee-agencies-todownsize-u-s-operations-idUSKBN1EF2S5

Tuan, Y. (1990). Topophilia: A study of environmental perception, attitudes, and values. New York: Columbia University Press.

United Nations High Commission for Refugees. (2018). Resettlement in the United States. Retrieved from http://www.unhcr.org/en-us/resettlement-in-the-unitedstates.html?query=refugees united states

United States Committee for Refugees and Immigrants. (2007). Resource Guide for Serving Refugees with Disabilities (pp. 1-139, Publication).

United Stated Department of State. (2018). The Reception and Placement Program. Retrieved from https://www.state.gov/j/prm/ra/receptionplacement/index.htm

United States Mission to the United Nations. (2017, December 2). United States Ends Participation in Global Compact on Migration. Retrieved from https://usun.state.gov/remarks/8197

Van Wing, S., \& Greenstone, S. (2016, May 17). Are African-Americans Really Leaving Portland? Retrieved from https://www.opb.org/radio/programs/thinkoutloud/segment/oregon-portland-africanamericans/

Wiewel, W. (2017). Portland State is a sanctuary university. Retrieved from https://www.pdx.edu/insidepsu/portland-state-is-a-sanctuary-university 


\section{Appendix A. Glossary.}

Belonging (referenced on page 2). The feeling that one has a place within a cultural or social system. Two components of belonging are identified as "fit" and "valued involvement" (Hagerty at al., 1992, p. 173). This essentially means that a person both experiences and feels that they are filling a valuable role within a system, and that they "fit in" with the system that they are within.

Maslow's Hierarchy of Needs (1987) (referenced on page 5.)Maslow theorized that psychological needs (such as stable housing, access to water and food, clothing and sleep) must be obtained before a person can experience safety and security, love and belonging and selfactualization.

Orientalism (referenced on page 9). A European and American construction 'The Orient' is analyzed through Edward Said's theories of Imaginative Geographies recognize the ways in which geographical territories exist outside of the physical realm. As described in the Dictionary of Human Geography, “Orientalism represents a body of European knowledge, a geography of the Orient, which not only helped construct an imperial vision of particular places and subjects but displaced other voices, and indeed had material consequences as such ideas became the basis for forms of rule" (p. 9). Said emphasizes production and domination as two key concepts in understanding Orientalism and its impacts. The Orient was a construction, it has had material impacts. The implications of orientalism include the legitimization of colonization, among other critical shaping factors of imperialism that affect communities around the world today (Dictionary of Human Geography, 2009). 


\section{Appendix B. Interview questions.}

Estimated time: 30 minutes or less

Participants were given a twenty five dollar visa gift cards and a TriMet transit bus day

pass.

A. For general participants:

1.How long have you lived in Portland, Oregon?

2.How long have you lived in the United States of America?

3.Where did you move here from?

4.Since you have moved here, what organizations have offered you assistance or support?

5.What kind of services does IRCO provide for you?

6.What area do you live in? Do you live in the city of Portland or outside of the city?

7.Did you get to choose where you live?

8. What do you like about living in Portland, Oregon? What aspects of the city help you to feel comfortable and at home?

9. What is difficult about living in Portland, Oregon? What aspects make you feel uncomfortable and not at home?

10.Do you feel that it is affordable living in Portland?

11.Have your rents raised at all since you have moved here?

12. If they have, How much has your rent raised?

If they have not, skip question. 
Refugees of Color Navigate Gentrification and Racism in Portland, Oregon

13. If their rent has raised: How have the raising rents affected how comfortable you feel in Portland?

If their rent has not raised: If your rent increased in the future, how would that make you feel?

14.How long do you think you will live in Portland, Oregon?

15.Based on your experience, what do you wish you could change about Portland?

16. Have any of your friends or members of your community had to move from Portland? If yes, where did they move to? Why did they move there?

17.If you could live somewhere other than Portland, where would you move and why? Estimated time: 40 minutes or less

B. For participants who are both refugees and work at IRCO:

1.How long have you lived in Portland, Oregon?

2.How long have you lived in the United States of America?

3. Where did you move here from?

4.When you moved here, what organizations have offered you assistance or support?

5. Did IRCO offer you support before you were employed by them?

6. How did you become involved in IRCO?

7.What area do you live in? Do you live in the city of Portland or a suburb? Do you live near IRCO?

8. When you first moved here, Did you get to choose where you live?

9.What do you like about living in Portland, Oregon? What aspects of the city help you to feel comfortable and at home? 
Refugees of Color Navigate Gentrification and Racism in Portland, Oregon

10.What is difficult about living in Portland, Oregon? What aspects make you feel uncomfortable and not at home?

11.Do you feel that it is affordable living in Portland?

12.Have your rents raised at all since you have moved here?

13. How much has your rent raised?

14.How have the raising rents affected how comfortable you feel in Portland?

15.How long do you think you will live in Portland, Oregon?

16.Based on your experience, what do you wish you could change about Portland?

17.Have any of your friends or members of your community had to move from Portland?

18.If you could live somewhere other than Portland, where would you move and why?

Estimated time: 1 hour or less

C. Additional questions for IRCO staff members that have been predetermined to already work with these issues:

Questions B 1-18

$\mathrm{C} 1$. What kind of programs does IRCO have to help refugees with rental assistance and reduced bill pay?

C2. Do you know of other organizations that help refugees locally?

C3. Why is IRCO important to you?

C4. What have some of the hardest issues been with your work?

C5. What kind of support can the government give to help alleviate the stress of raising rents for refugee families?

C6. Have you met very many refugees who have been affected by raising rents? What do they usually do to address this issue? 
Refugees of Color Navigate Gentrification and Racism in Portland, Oregon

C7. Do you know many people who have moved from Portland due to the raising rents?

- Where did they move to, and why did they consider that area?

- Have any of them come back?

If so, why?

Estimated time: 30 minutes or less

D. Questions for Resources Coordinator of Kateri Park or other Catholic Charities employee:

1. What kind of services does Catholic Charities offer for refugees?

- Are any of these service culturally specific?

1. What have some of the hardest issues been with your work?

3. What kind of support can the government give to help alleviate the stress of raising rents for refugee families?

1. Have you met very many refugees who have been affected by raising rents? What do they usually do to address this issue?

2. Do you know many people who have moved from Portland due to the raising rents?

- Where did they move to, and why did they consider that area?

○ Have any of them come back?

$\circ$ If so, why 


\section{Appendix C: East Portland Neighborhood Office's Anti-Displacement Recommendations.}

EPNO recommends these sixteen items as actions against displacement:

- EPAP Civic Engagement Grants (allocating money for language, racially, ethnically and culturally specific projects for underserved and underrepresented communities)

- Living Wage Provisions (acknowledging that most people in East Portland make less than other neighborhoods)

- Local Hiring (this requires all developers and contractors to hire from East Portland, with an additional emphasis put on hiring women and minorities).

- the Community Benefits Agreement (CBA) and highlights the ways in which the construction of David Douglas high school developers hired minorities)

- Minority Contracting

- Commercial Stabilization

- Commercial Rent Stabilization (using many of the tools of Neighborhood Prosperity Initiatives (NPIs) and Main Street Projects)

- Community Reinvestment Act (mandating banks and hospitals to reinvest within 3 to 5 miles of their facilities)

- Commercial Transit Oriented Development (TOD)

- Owner Occupied Homeownership for People with Lower Income,

- Rent Stabilization (mandating that all rental increases are reasonably gradual)

- Just Cause Eviction (JCE) 
- Code Enforcement

- Renter Education (this will enable more security and stability for renters, with more attention given to their living conditions and their awareness of their rights as tenants)

- Broadening Homeownership

- Cooperative Ownership (allowing some barriers to home ownership to be removed)

- Inclusionary Zoning,

- Housing Acquisition Rehabilitation to Insure Affordability,

- No Net Loss/Affordable Housing Preservation Ordinance,

- Community Benefits Agreement (CBA)

- Anti-Displacement Impact Analysis (East Portland Neighborhood Office, 2015, pg.5). 